Pamiętnik Literacki 2001, 2, s. 5-36

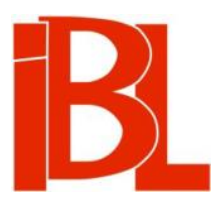

\title{
Mimesis Platona
}

\author{
Arne Melberg
}




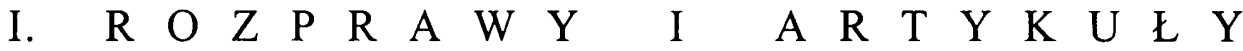 \\ Pamiętnik Literacki XCII, 2001, z. 2 PL ISSN 0031-0514}

ARNE MELBERG

\section{MIMESIS PLATONA*}

\section{Krytyka}

Platon skazał poetów na wygnanie.

Najbardziej znanym fragmentem, w którym pojawia się ów dramatyczny gest, jest dialog Państwo, ks. X - ostatnia, gdzie Platon każe Sokratesowi dojść do wniosku, iż „z utworów poetyckich wolno dopuszczać do państwa jedynie tylko hymny na cześć bogów i pochwały dla ludzi dzielnych" (607 A)'. Państwo odsyła do idealnego miasta-państwa, które Sokrates naszkicował zyskując przychylność młodych słuchaczy, opór napotyka zaś w ks. I, gdzie niejaki Trazymach wygłasza skandaliczną przemowę sławiącą niesprawiedliwość. Przemowa ta staje się dla Sokratesa pretekstem, by zbadać relacje między prawdą, prawem i dobrem; zapał pedagogiczny wiedzie go dalej ku teorii poznania oraz nauce o państwie, ponadto do poezji, a przez to także do poetyki i estetyki.

Powody, dla których poetom odmówić należy wstępu do państwa idealnego, są natury zarówno teoriopoznawczej, jak i moralnej, mają jednak wspólny mianownik: mimesis. Platon używa słowa przede wszystkim w znaczeniu sygnalizującym relację wizualną: mimesis sugeruje obraz, odzwierciedlenie, imitację, mimikę. Sztuka jest źródłem wiedzy mizernej i niepewnej, twierdzi Sokrates (wciąż w ks. X Państwa), ponieważ daje odzwierciedlenia z trzeciej ręki. Najbliżej prawdziwej rzeczywistości stoi filozof: widzi formy rzeczy i nie zważa na odzwierciedlenia. Gdy Platoński rzemieślnik sporządza swą sofę, oddala się od formy. Kiedy zaś artysta odzwierciedla sofę zrobioną przez rzemieślnika, doszliśmy do trzecie-

* Przekład według: A. M e l b e r g, Mimesis - en repetition. Stockholm-Stenhag 1992, rozdz. Platons mimesis, s. 7-56.

1 A. Melberg tu i dalej cytuje Platona w przekładach z lat 1920-1926 (P l a t o, Skrifter. I svensk tolkning av C. L i n d s k o g. T. 1-6. Stockholm 1920-1926), modyfikując je przez porównanie głównie $z$ angielskim przekładem równoległym w serii „The Loeb Classical Library”, np. konsekwentnie zmienia „naśladowcę" $z$ thumaczenia Lindskoga na „mimetyka”. Wszystkie cytaty z Platona lokalizowane są przez podanie powszechnie przyjętej numeracji wprowadzonej przez Stefanusa do wydania zbiorowego pism filozofa w r. 1578. W tym artykule zostały wykorzystane przekłady W. W it w i c k i e g o dialogów P l a t o n a: Fajdros. Warszawa 1958; , ,Państwo" z dodaniem siedmiu ksiag „Praw”. T. 1-2. Warszawa 1958; Timaios. W: „Timaios" i „Kritias”. Warszawa 1960; Uczta. W: Uczta. - Eutyfron. - Obrona Sokratesa. - Kriton. - Fedon. Warszawa 1984, oraz przekład W. S tef a ń s k i e g o - Kratylosa (Wrocław 1990). W kilku miejscach cytaty uzupełniono tekstem w nawiasach kątowych, tj. tłumaczeniem wersji przyjętej przez Melberga. [Przypis thum.] 
go poziomu naśladownictwa. „Więc tym samym - stwierdza Sokrates - będzie $\mathrm{i}$ autor tragedii, jeżeli jest naśladowca, on będzie kimś trzecim $\mathrm{z}$ natury, licząc od króla i od prawdy, i wszyscy inni naśladowcy tak samo" (597 E). Niemoralność sztuki wywieść teraz już można z jej mimetycznego przekleństwa: odwołuje się ona do zwodniczej wiedzy czerpanej z doznań zmysłowych, co oznacza, iż apeluje do naszych gorszych cech, imituje raczej „usposobienie skłonne do wybuchów i raz takie, a raz inne" (605 A) niż idealny spokój czy idealne dobro, ponadto wzmaga wątpliwy „element ciemny 〈uczucie rozkoszy)” (605 B), nie zaś idealne i prawdziwe spełnienie.

Dla nas, żyjących dzisiaj, brzmi to zapewne jak drętwe moralizatorstwo, oparte na grząskim gruncie, tzn. zbudowane na wątpliwej analogii zachodzącej między sztukami pięknymi, poezją i dramatem (tragedia). Dla Platona związek moralności z poezją wynikał ze wspólnego mianownika, którym była mimesis: słowa za sprawą mimetycznych sztuczek wywołuja obrazy, fantazje, fantomy - powracają określenia ,phantasma" i ,eidolon” - spośród sztuk związanych ze słowem najwyżej stoi dramat, z kolei ze sztuk dramatycznych najwyżej umiejscowiona jest tragedia, a pierwszy $z$ poetów to Homer, zwany dlatego ,przodownikiem tragedii” (598 D), i to właśnie on dostarcza Sokratesowi przykładów literatury wartej odrzucenia.

Wygnany zostanie więc z państwa każdy, j e ż e li w swej sztuce wykorzystywać będzie mimesis, ,jeżeli jest naśladowcą" (597 E) - jak napisano w zacytowanych właśnie dociekaniach teoriopoznawczych. Słówko ,jeżeli” przysparza w tej argumentacji kłopotów, nadając jej wpierw charakter hipotetyczny, następnie zaś płynny. Platon każe Sokratesowi za pomocą owego ,jeżeli” sondować teren, a później zaskakuje wnioskiem, w którym nie ma już hipotetycznych zastrzeżeń. Tok argumentacji w ks. X Państwa ilustruje ową płynność: na początku Sokrates przypomina wcześniejsze dociekania o mimesis poetyckiej, przede wszystkim w ks. III, i oświadcza, że utwierdził się w przekonaniu, iż słuszne było odrzucenie mimesis poetyckiej, mówiąc ściślej: „tej 〈części〉 poezji, która naśladuje” (595 A). Części! W podtekście wyczytać tu można, że mimetyczne są tylko c z ęś c i poezji, lub też że jedynie pewne pi e rw i a stk i poezji opierają się na mimesis a zatem poezja zawiera lub zawierać może pierwiastki inne od mimetycznych, dlatego też mimesis jest chwytem w sztuce, jednym z jej środków wyrazu. Platon/ Sokrates zakłada: gdybyśmy tylko mieli wiedzę o istocie sztuki traktowanej jako „lekarstwo w postaci wiedzy", to potrafilibyśmy trzymać się moralności i oprzeć się mimetycznemu uwiedzeniu przez sztukę.

Po przejściu owego „teoriopoznawczego magla” okazuje się jednak, iż mimesis właśnie stanowi istotę sztuki. Żadne lekarstwo już nie wystarcza, wszelkie zastrzeżenia znikają jak kamfora, zakłada się, że doszliśmy do takiego wniosku: mimesis jest konstytutywną częścią sztuki i poeci en bloc są mimetykami. Sokrates zapewnia:

Więc tośmy już, zdaje się, należycie uzgodnili, że naśladowca nie wie nic godnego uwagi o tym, co naśladuje; naśladownictwo [mimesis] to jest pewna zabawa [paidia], a nie zajęcie poważne, a ci, którzy się bawią pisaniem tragedyj w jambach i heksametrach, wszyscy są naśladowcami w najwyższym stopniu. [602 B]

Żaden z pokornych słuchaczy Sokratesa nie odważa się wtrącić jakiegoś ,jeżeli”, by przypomnieć o wcześniejszych zastrzeżeniach, nikt nie wydobywa „le- 
karstwa" i nikt nie zastanawia się, dlaczego poetyckie igraszki (,paidia”), których nie można traktować serio, uważane są jednak za tak doniosłe, iż trzeba usunąć je $\mathrm{z}$ miasta.

Nie jest to, rzecz jasna, jedyny fragment, w którym Platon rozprawia się $z$ poetami, $z$ pewnością jednak najbardziej efektywny dramatycznie i najbardziej znany. Wydaje się też, że najmniej w nim zastrzeżeń - gdyby pominąć owo ,jeżeli”. Innymi słowy: w rozumowanie wpisana jest pewna wątpliwość czy też płynność, dlatego centralne pojęcie, mimesis, staje się wieloznaczne; tę wieloznaczność wyczytać jednak da się również z terminów otaczających i podpierających samo pojęcie, takich jak „,obraz [eidolon]”, ,,gra [paidia]”, „,lek [pharmakon]”. Tego rodzaju płynność i dwuznaczność uznać chyba można za kłącza owego tajemniczego paradoksu, którego Platon, dystansując się wobec poetyckiej mimesis, nigdy nie formułuje wprost, w obrębie którego jednak wciąż się porusza: otóż samo odrzucenie sformułowane jest w kategoriach mimetycznych. Będąc poetą - Platon skazuje poetów na wygnanie.

Zagadka ta kusi do znajdywania rozwiązań, paradoks stanowi wyzwanie dla właściwej każdemu czytelnikowi potrzeby konstytuowania w miarę stabilnego i jednoznacznego sensu - zapytać można, czy cały „platonizm” nie składa się właśnie $z$ rozwiązań owych zagadek i paradoksów, które odkładają się w Platońskich dialogach i tworzą tekst Platona. Będę tutaj tak dalece, jak to tylko możliwe, trzymał się tekstu (a zatem także paradoksu), ale spróbuję uniknąć rozwiązań „platonizmu”.

Aby posunąc się dalej w interpretacji Platońskiego tekstu, przejdźmy zatem do pozostałych fragmentów, w których filozof skazuje poezję na banicję. Wpierw powróćmy do Państwa, do ks. I i III. Znajdujemy tam podstawy do sądów wyrażonych w ks. X, ponadto techniczne, szczegółowe dociekania o poezji mimetycznej - coś na kształt Platońsko-Sokratesowskiej poetyki.

Jej punkt wyjścia stanowi moralność. Powodem, dla którego Sokrates ujawnia swoje obawy dotyczące fatalnych oddziaływań literatury, jest to, iż rozmowa zeszła na pedagogikę, rzecz jasna, po skandalicznym przemówieniu Trazymacha wysławiającym niesprawiedliwość (Sokrates, oczywiście, unicestwia je swymi argumentami). Opowieści dla dzieci trzeba cenzurować, oświadcza Sokrates. Opowieści kłamią i dlatego należy je zwalczać, w szczególności te, które „nie budzą rozumu 〈są wstrętnymi kłamstwami〉" (377 D). Przykład podany przez Sokratesa wykazuje, iż kłamstwo zawarte w opowieści odnosi się do bogów. Ponieważ zaś bogowie $z$ definicji - z definicji Platona - są dobrzy, kłamstwem jest ukazywanie ich w niekorzystnym świetle. Jako przykład została przywołana tu opowieść Hezjoda o stworzeniu świata, w której pojawia się i ojcobójstwo, i kastracja - cóż, Sokrates wprawdzie o niej nie wspomina, ale zakłada, że rozumiemy, o co chodzi. Albo też słynna replika Achillesa z ostatniej księgi Iliady, gdzie powiada się o szefie bogów, Zeusie, że przynosi ludziom tyleż dobrego, co złego.

Te dwa najważniejsze przykłady interesujące są z kilku powodów: pierwszy dlatego, iż podejmuje temat ojcobójstwa (przez to, iż go nie podejmuje) - motyw u Platona wciąż powracający, choć mało widoczny. Drugi (o Achillesie) - ponieważ inauguruje systematyczną krytykę Homera przez Platona, w szczególności zaś Iliady. Przykład ten to najlepszy z możliwych punktów wyjścia do takiej krytyki: replika Achillesa, który mówi o Zeusie beztrosko mieszającym składniki życia ludzkiego $\mathrm{z}$ dwóch urn (,Z jednej $\mathrm{z}$ nich czerpie $z \nmid e$, a $\mathrm{z}$ drugiej dobre on dary”, 
I XXIV 524) ${ }^{2}$, jest punktem kulminacyjnym, lecz oznacza także stopniową metamorfozę gniewu Achillesa, będącego wszakże motywem scalającym Iliadę. Platon/Sokrates formułując sąd krytyczny wskazał na zakończenie i punkt kulminacyjny Iliady - więcej na ten temat w rozdziale Repetycja Homerowa.

Tutaj staje się to punktem wyjścia do pierwszej dyskusji wokół Platońskiej mimesis, traktującej o obrazie i odbiciu (,bild och avbild”). Kłamstwa rozpowszechniane przez opowieści nie są autentycznymi kłamstwami, twierdzi Sokrates, ale odbiciami kłamstw. Czy zatem da się wyciagną̧c stąd wniosek, iż fałszywe słowa, w przeciwieństwie do kłamstw rzeczywistych, mogą mieć wartość pedagogiczna, np. jako pharmakon chroniące przed większym złem? Sokrates zadaje to pytanie (382 C, D), ale waha się, gdy należy na nie odpowiedzieć, tzn. wpierw na pozór zgadza się z tym, iż w świecie fikcji (,to pseudos”, 382 D) mimetyczne kłamstwo jest złem koniecznym, dokonuje jednak natychmiast porównania $\mathrm{z}$ idealnym światem bogów i owo porównanie nie wychodzi na korzyść fikcji, bóg/ ideał jest wszak właściwym światem i stąd też nie może być zainteresowany pseudoświatem obrazów. „W bogu nie ma - twierdzi Sokrates - poety, który kłamie”: słowo „pseudos” występuje w tym urywku (382 D) trzy razy jako określenie świata odbić, mimetycznego półświata.

W dyskusji wstępnej po raz pierwszy mimesis Platona jawi się nam jako pojęcie płynne, co uwydatniają słowa ,pseudos" i ,pharmakon”. Ostatnie z nich oznacza zarówno truciznę, jak i lek, Platon balansuje między owymi połączonymi przeciwieństwami, zatem mimesis może być przepisywana jako lekarstwo, używana w formach kontrolowanych i umiarkowanie, a w następnej chwili odrzuca się ją jako truciznę. Pseudoświat - mówi Sokrates nieco dalej - nie jest obiektem zainteresowania bogów, ale może być użyty przez ludzi jako pharmakon (389 B), i wyprowadza $z$ tego wniosek, iż oszustwa mimetyczne pozostawić trzeba ekspertom, którzy wiedza jaką dawkę należy zastosować! W istocie to sam Platon jest uzależniony, $\mathrm{z}$ uporem używa bowiem formy dialogu, czyli mimetycznego pseudoświata ex definitione, by ukazać nie skażony mimetyzmem świat idei.

Był to pierwszy niepewny krok w argumentacji, jego wynikiem jest w ks. III Państwa skazanie poetów na wygnanie, powtórzone później i udramatyzowane w zacytowanym już fragmencie ks. X. Kolejny krok polega na tym, iż Sokrates podaje szereg przykładów z Iliady i Odysei, dotyczących opowieści lub ich części, które wykorzenić trzeba z pedagogiki. Bynajmniej nie dzieje się tak dlatego, jak zapewnia Sokrates, że mamy do czynienia ze złą poezją. Wręcz przeciwnie. Chodzi o poezję piękną, „ale im bardziej [opowieści] są poetyczne, tym mniej się nadają do słuchania dla dzieci i ludzi dojrzałych, którzy powinni być wolni" (387 B) - formułuje się tu po raz pierwszy, jeśli się nie mylę, argument powracający później we wszelkiej estetyce o charakterze etycznym i krytycznym. Przykładem może być Rousseau dochodzący do wniosku w swej krytyce identyfikacji w teatrze - czyli swego rodzaju mimesis - że im lepsza komedia, tym bardziej „szkodliwa dla obyczajów”3.

2 Cytaty z dzieł Homera podano za: H o m e r, lliada. Przełożył oraz opatrzył wstępem i słowniczkiem imion własnych I. W i e n i e w s k i. Ilustracje: S. Wy s p i a ń s ki. Kraków 1984; Odyseja. Przełożył i wstępem poprzedził J. Parandowski. Słownik imion, nazw i rzeczy opracował S. J. K o ł o d z i e j c z y k. Warszawa 1959. W zastosowanych skrótach litera odsyła do tytułu eposu, liczba rzymska do księgi bądź pieśni, arabska zaś do wersu. [Przypis thum.]

3 J. J. R o u s s e a u, La Lettre à Mr. d'Alembert (1758). Genève 1948, s. 45. 
Naczelną postacią w owych przykładach jest bohater nad bohaterami, Achilles. Wspomniano już jego wyzbyte iluzji poglądy na temat bogów; Sokrates osądza go teraz za ogólny „brud połączony z chciwością, a z drugiej strony - butę w stosunku do bogów i ludzi" (391 C), dobitny dowód stanowi pełen pogróżek opór przeciw Apollonowi (zob. I XXII 15) i Skamandrowi (zob. I XXI 123). Równie fatalne jest to, iż Achilles po śmierci gorzko skarży się na swój los Odyseuszowi odwiedzającemu Hades: „Wolałbym za parobka służyć na cudzej roli, u biednego chłopa, który ledwo się może utrzymać, niż tu panować nad wszystkimi, co znikli ze świata" (O XI 489-491; s. 207). Także i to, że jest bohaterem przepełnionym wątpliwościami, kapryśnym, a po śmierci Patroklosa - wręcz wycieńczonym, ogarniętym bezsennością (zob. I XXIV 10). Przypomina się tu wzburzenie Hegla podczas lektury Księcia Homburgu Kleista: pragnął, aby bohaterowie sztuk byli jednoznaczni, zgodnie z zasada, iż „Katon żyć może jedynie jako republikanin i Rzymianin" (zatem, że dwuznaczny Katon nie jest już Katonem), wyprowadziła go dlatego $z$ równowagi postać buntowniczego, pełnego wątpliwości, ogarniętego lękiem przed śmiercią Kleistowskiego księcia, który na domiar wszystkiego zapada w sen! ${ }^{5}$

Powrócę jeszcze do Platońskiej rozprawy z Homerem i głównym bohaterem Homerowym, Achillesem. W przykładach użytych w argumentacji Sokratesa chodziło o treść i przedmiot opowieści (,logos”), dalej (392 C) przechodzi się do formy i sposobu przedstawiania (,leksis"). Jeden z przykładnych słuchaczy twierdzi, iż nie jest w stanie pojąć rozróżnienia między c o a ja k opowieści, tak więc Sokrates zyskuje możliwość, by poprzez zbadanie, w jaki sposób mimesis funkcjonuje także jako technika i chwyt artystyczny (nie tylko jako obraz/odbicie, lecz także jako forma odzwierciedlania), zainicjować naukę o narratologii ${ }^{6}$. Definicja jest prosta: mimesis oznacza oddanie opowieści (,diegesis”) w sposób mimetyczny (,dia mimiseos"), tj. przez bezpośrednie przytoczenie, głosem kogoś innego, w odróżnieniu od opowiadania głosem własnym - chwyt, który Sokrates nazywa opowiadaniem „prostym” i ,czystym” (393 C, 394 B). Przykład po raz kolejny zaczerpnął z Iliady: tym razem z introdukcji, gdzie Homer wpierw opowiada, jak Chryzes błagał pochodzącego z wyższego rodu Agamemnona o córkę, szybko jednak przechodzi do udramatyzowanej formy przedstawienia, przez Platona zwanej mimesis. Czyli używając słów Sokratesa: Homer opowiada tak, ,jakby on sam był Chryzesem, i stara się w nas, ile możności, wywołać to wrażenie, że to nie Homer mówi, ale kapłan, starzec. I całą resztę opowiadania mniej więcej tak prowadzi [...]" (393 B). Dla jeszcze większej wyrazistości Sokrates opowiada na nowo ten sam epizod w sposób niemimetyczny, tzn. rezygnuje $z$ bezpośrednich przytoczeń, korygując zatem już nie tylko Homera, ale i samego Platona, przedstawiającego wszakże wszystkie owe dociekania na temat mimesis jako chwytu narracyjnego, wraz z krytyką mimesis, w formie opowiadania zdefiniowanej przez Sokratesa jako mimetyczna.

4 G. W. F. H e ge l, Vorlesungen über die Ästhetik. Frankfurt am Main 1970, s. 98. Werke. T. 13 .

5 Zob. G. W. F. H e g e l, Hegel in Berlin. Berlin 1981.

6 Platon był, rzecz jasna, narratologiem avant la lettre, gdyż termin wszedł w użycie i został rozpowszechniony dopiero za sprawą francuskich strukturalistów posługujących się nim w analizie tekstów narracyjnych, tj. począwszy od lat sześćdziesiątych XX wieku. Krótką historię terminu odnaleźć można w G. Ge ne t t e'a Nouveau discours du récit (Paris 1983, s. 10-15). 
W ostatnich ustępach Poetyki Arystotelesa, pisanej prawdopodobnie wkrótce po powstaniu Państwa, odnajdujemy apoteozę Homera. Jego wielką zasługą jest, iż w pierwszej osobie opowiada tak mało, jak to tylko możliwe, ale ,po krótkim osobistym wstępie - wprowadza natychmiast na scenę męża, niewiastę czy jakąś inną postać [...]" $\left(1460^{\mathrm{a}} 8-10\right)^{7}$. Wydaje się w istocie, że mamy tu bezpośrednią polemikę ze streszczonym i cytowanym już fragmentem Państwa, gdzie Homerowi zarzuca się właśnie to, co Arystoteles wychwala. Nawet jeśli pominąć kwestię polemiki ${ }^{8}$, wydaje się osobliwe, iż oba pisma będące wrotami prowadzącymi na gościniec myślenia okcydentalnego kierują się ku temu samemu tekstowi i temu samemu zjawisku w owym tekście. Oraz, rzecz jasna, że wartościują opowieść Homerową w sposób diametralnie różny i przez to stają się preludium do zażartych polemik na temat mimesis. Nowoczesna krytyka sztuki opowiadania - od Henry'ego Jamesa aż po dzień dzisiejszy - stanęła, jak wiadomo, po stronie Arystotelesa i faworyzuje opowieść udramatyzowaną przekładając ją nad streszczenie, zwane przez Platona czystą diegesis. Pod nazwą ,showing” oraz ,telling” Platońskie rozróżnienie stało się, by użyć określenia Gérarde'a Genette’a, „Ormuzdem i Arymanem estetyki powieściowej w normatywnej, anglo-amerykańskiej wulgacie"9. Jeśli jednak współczesna narratologia odwróciła wartościowanie Platona i podążyła za Arystotelesem, porzuciła też praktykę Platona i zastąpiła Platoński dialog Arystotelesowską analiza. Platon pozwala sobie na krytykę mimesis w mimetycznych dialogach. Ów paradoksalny sposób przedstawiania i zachowania się sugeruje, iż - nawet po zapoznaniu się z ocenami Sokratesa zawartymi w Państwie - bynajmniej nie uporaliśmy się jeszcze $z$ Platońską oceną mimesis i że kwestią otwartą pozostaje, kto - Platon czy Arystoteles - wyżej wartościuje opowiadanie. A także: którą formę opowiadania Platon tak naprawdę ocenia najwyżej.

W mojej interpretacji mimesis Platońska jest pojęciem dynamicznym, każda zaś próba uczynienia go mniej czy bardziej stałym i jednoznacznym sabotuje zarazem ową płynną wieloznaczność. Różne sensy, które nadawano terminowi w jego długiej historii w przekładach, sugeruja, iż jest on nader pojemny, nawet jeśli konotacje sceniczne i wizualne wydają się constans w określeniach takich, jak: „imitacja”, „odzwierciedlenie”, „przedstawienie [Darstellung]”, „reprezentacja”, „odbicie”, „naśladownictwo [Nachahmung]”. Kiedy Platon w ks. III Państwa każe Sokratesowi rozwinąć rozróżnienie między mimesis a diegesis, nie idzie o ograniczenie terminu do kwestii narracyjnej bądź składniowej, mianowicie do użycia bezpośredniego przytoczenia (,Platon nie zwykł awanturować się tak bardzo o dystynkcje gramatyczne" - jak ujmuje rzecz Gerald F. Else ${ }^{10}$ ), ale chce uzasadnić

7 A. Melberg tłumaczy Arystotelesa poprzez komentowany przekład G. F. Els e’a Aristotle's Poetics. The Argument (Cambridge, Mass., 1957), porównując go ze szwedzkim przekładem J. S t o lp e g o. W tłumaczeniu polskim cytaty z Arystotelesa podano za: A r y s t o te le s, Poetyka. Przełożył i opracował H. P od b i els k i. Wrocław 1983. BN II 209. Zarówno u Melberga, jak i w wersji polskiej przy lokalizacji cytatów posłużono się numeracją standardowa, tj. pochodzącą z ciagłej numeracji wydania zbiorowego wszystkich pism filozofa. [Przypis tłum.].

${ }^{8}$ Główna teza G. F. El s e'a (Plato and Aristotle on Poetry. Chapel Hill 1986): Arystoteles formułował swą Poetykę w opozycji do Platona, ten zaś włączył potem do własnej koncepcji część poglądów Arystotelesa.

${ }^{9}$ G. G e ne t te, Narrative Discourse. Transl. J. E. Lew in. Foreword J. Culler. Ithaca 1980, s. 163.

${ }^{10} \mathrm{E}$ l s e, Plato and Aristotle on Poetry, s. 25. 
pierwsze wygnanie poetów (398 A), będące $\mathrm{z}$ kolei preludium do generalnej rozprawy z mimesis, do czego dochodzi w ks. X.

W drodze ku owemu pierwszemu wygnaniu następuje jednak kilka osobliwych zdarzeń. Sokrates zwraca się do siebie i do nas z pytaniem, jaka dawka opowiadania mimetycznego (w przeciwieństwie do diegetycznego) może być wskazana w czasie wychowywania strażników mających kierować jego państwem: „czy nasi strażnicy powinni być zdolnymi naśladowcami, czy nie" (394 E). Łatwo zgadnąć, że przynajmniej Sokrates nie chce mieć w państwie żadnych mimetyków, pierwszy powód jest jednak zaskakujący: spowodowałoby to niefortunny podział pracy. Strażnicy, od których oczekuje się, by znali się niemal na wszytkim, mogą zejść na złą drogę, jeśli sprowokuje się ich do zachowań mimetycznych. Także uzdolniony mimetyk, twierdzi Sokrates, nie może być równie sprawny przy wykonywaniu różnych prac, „skoro nawet $w$ dwóch pozornie bardzo bliskich rolach nie potrafi jeden i ten sam człowiek dobrze występować, na przykład pisać komedie i tragedie (w dwóch tak bliskich sobie formach mimesis, jak komedia i tragedia)" (395 A).

Dlaczego jednak nie? - powinni teraz zdziwić się oddani słuchacze Sokratesa. W każdym razie czytelnik Platona ma prawo zapytać, jak twierdzenie Sokratesa o niemożliwości połączenia talentu komediowego i tragicznego ma się do twierdzenia tegoż Sokratesa, które wygłosił w innym dialogu, mianowicie w Uczcie: „kto jest artystą w tragedii, ten i komediopisarzem być potrafi” (223 D). Powrócę jeszcze do tej kwestii, już teraz jednak pojawia się podejrzenie, iż za dwoma niemożliwymi do pogodzenia twierdzeniami kryje się pewna myśl Platońska, mianowicie dyskretna obrona praktyki mimetycznej samego Platona, jego dialogu filozoficznego, nie będącego w sposób oczywisty ani tragedią, ani komedią, ale odrębną formą dramatyczną zawierającą składniki ich obu.

To jeszcze nie koniec osobliwości - zachowań mimetycznych należy unikać w procesie wychowawczym, uważa Sokrates, przeradzają się bowiem w przywarę:

Czyś nie zauważył, że odgrywane role, jeżeli się je od dziecięcych lat rozpoczyna i praktykuje w dalszym ciągu, wchodzą w obyczaj i naturę - zarówno jeżeli o ciało chodzi, jak o sposób mówienia i myślenia. [395 D]

Platon powinien o tym wiedzieć, powinien jednak wiedzieć także, iż przykłady przywar nałogowego mimetyka, które każe potem wymienić Sokratesowi, mają niewiele wspólnego z dramatem czy opowiadaniem, a już zupełnie nic ich nie łączy z Homerem. Sokrates twierdzi bowiem, że mimetyk naśladuje, co tylko się da, także to, czego imitować nie należy: niewolników, kobiety, konie rżące (!), byki ryczące (!), owce (!), rzeki szumiące (!), morze huczące (!), grzmoty (!), trąby (!), flety (!) (396 A, B; 397 A). Im zręczniejszy jest mimetyk, tym gorszym okazuje się opowiadaczem - tak, zdaje się, uważa Sokrates - chodzi zapewne o zdolności czysto techniczne, które konfrontuje on z moralnymi. Opowiadanie diegetyczne broni szańców moralnych, natomiast uzdolniony mimetycznie opowiadacz wiedzie i wiedziony jest do rzeczy wartych odrzucenia, jeśli rozpatrywać je z perspektywy moralności: „im będzie lichszy, tym bardziej będzie wszystko naśladował" (397 A). Stąd też diegetykowi pozwala się na pozostanie w państwie, natomiast mimetyk zostaje wygnany $(398 \mathrm{~A})$.

Kto jednak tak naprawdę pada ofiarą owego pierwszego wygnania? Swoją argumentację Sokrates rozpoczyna od Homera, kończy jednak na mimetyku w ni- 
czym nie przypominającym wzniosłego śpiewaka, a będącym raczej kuglarzem i sztukmistrzem, który oddaje się imitacji zwierząt i zjawisk atmosferycznych. Śpiewak kryje w sobie kuglarza lub też ma dwoistą naturę, diegetyczną i mimetyczną - gorsza połowa zostaje skazana na wygnanie. Zaklinając się na swój honor Sokrates zapewnia, iż jeśli takowy kuglarz pojawiłby się w państwie:

przyjęlibyśmy [go] z wielkim szacunkiem jako istotę godną czci i podziwu i sympatyczna, ale byśmy powiedzieli, że u nas w mieście takich nie ma, i nie trzeba, żeby się tacy między nami zamnażali, więc odesłalibyśmy takiego do innego miasta wylawszy mu perfumy na głowę i uwieńczywszy go przepaską wełnianą [...]. [398 A]

W wyroku banicji, na którą Sokrates skazuje mimetyków, brakuje chyba tylko namydlonego pala; mam na myśli owe ironiczne pokłony przypominające to, co w obrzędach ludowych spotykało króla-na-jeden-dzień i inne postaci kozłów ofiarnych, zanim nasmarowano je oliwa, obtoczono w pierzu i wygnano lub zlinczowano. Nie powinniśmy zapominać, gdyż i Platon nie zapomniał, że poniżony ma być w naszych oczach sam Homer. Platon każe Sokratesowi przypomnieć nam o tym w ks. X, przy okazji drugiego wygnania: tam wątki się splatają, a niepewność pozostawia się na stronie. Tam też dowiadujemy się, jak już wcześniej wspomniałem, że Homer jest ,,przodownikiem tragedii” (598 D) i pierwszym spośród poetów (600 E) oraz że poeci, niezależnie od tego, co i gdzie pisza, ,wszyscy są naśladowcami" (602 B). Określenie oznaczające poetę stało się tym samym co słowo charakteryzujące trudniącego się naśladownictwem kuglarza, któremu w ks. III zabroniono poważnego opowiadania i którego wygnano z państwa. Zaraźliwa trucizna mimesis zainfekowała swe otoczenie tak, iż ani opowiadanie diegetyczne, ani wiedza nie są już przydatne jako lek.

\section{Wizja}

Mimesis poetycką odrzuca się jako zabawę i kuglarstwo, ale odrzuca się ją z powaga tak jakby chodziło o śmierć albo życie. W istocie, w Platońskiej mimesis stawką jest życie, i to w kilku znaczeniach: za odrzuceniem poezji mimetycznej kryje się coś, co określić chcę wstępnie i posługując się w tym kontekście anachronizmem - mianem „utraty »ja«". Lub też raczej lękiem przed tęsknotą oraz/albo za ,utratą »ja«". Jak pamiętamy, Sokrates uczynił Homera arcymimetykiem w momencie, kiedy ten naśladować zaczął słowa kogoś innego, wypowiadał się jak ktoś inny, s tał $\mathrm{s}$ i ę kimś innym. Od tej chwili mimetyk skazany jest na bycie czymś lub kimś innym, a nie samym sobą. Owo ,ja" skazane jest jednak równocześnie na poszukiwanie siebie/swego ,ja"w kimś innym, a poszukiwanie to odbywa się mimetycznie, przez naśladownictwo.

Trzecie wygnanie poetów przez Platona wprowadza nas bezpośrednio w owe paradoksy, ale dzięki temu wyprowadza nas także z poetologiczno-ideologicznych okopów, które wzniesiono w Państwie. Trzecie wygnanie odbywa się w sposób raczej dyskretny, w Prawach, czyli w dialogu uchodzącym za ostatnie dzieło Platona, a mówi o tym ,nieznany Ateńczyk" gawędzący w nader przyjemnych okolicznościach, gdzieś na Krecie, z człowiekiem z samej Krety i z pewnym Spartaninem. Sokrates nie pojawia się w owym dialogu traktującym ponownie o państwie idealnym, tym razem umiejscowionym na Krecie, a zaludnionym przez 5040 
szczęśliwców - liczbę tę wybrano ze względu na jej łatwą podzielność, przez co państwo staje się proste $w$ administracji. Potrzeba poezji w owym dobrze podzielnym państwie jest, rzecz jasna, niewielka, wspomina się ją jednak przy pewnej okazji w ks. VII, kiedy „,nieznany Ateńczyk” nagle stwierdza zaskoczony, iż prowadzone dotąd dyskusje ,ze wszech miar brzmią jak jakaś poezja” (811 C). Państwo, które zbudował w myślach, imituje idealne życie i w tym sensie jest poetyckim konstruktem na wzniosły temat, toteż stanowi „naśladowanie najpiękniejszego i najlepszego życia. My twierdzimy, że to jest istotnie tragedia najprawdziwsza" (817 B). Jeśli więc $w$ idealnym państwie pojawi się poeta $z$ tragedią pod pachă, dowie się, że jest zbędny, ci bowiem, którzy w nim żyją, sami są tragikami i poetami w najlepiej skonstruowanym ze wszystkich możliwych dzieł sztuki.

Rozmowy dotyczyły zatem poezji wzniosłej. Przycinek trafia się jednak także owej zasługującej na pogardę działalności, nazwanej przez Platona w Państwie mimetyczną i kojarzonej z kuglarzami oraz mimami; bez dokładnego sprecyzowania mówi się o tym, że należy „kazać tego rodzaju naśladowanie wykonywać niewolnikom i obywatelom obcym, wynajętym, a poważnie takich rzeczy nie traktować nigdy ani trochę" (816 E). Aktywność mimetyczna jawi się więc jako rzecz warta odrzucenia w swej wersji komicznej, a zbędna w wersji tragicznej, tj. posługującej się stylem wysokim. Zarazem jednak mimesis jest elementem konstytutywnym wszelkiej wiedzy, twórczości i struktur społecznych, dyskusja filozoficzna i polityczna „nieznanego Ateńczyka” okazała się wszakże literaturą co oznacza, iż zasadza się na fundamencie mimesis, która przez to zmienia się z poetyki (jak w ks. III Państwa) w swego rodzaju antropologię. Lecz i ona jest skazana na banicję dopóty, dopóki ma charakter literacki!

Owo odrzucenie jednak równa się najwyższemu uznaniu. Co więcej, u Platona odnaleźć można wiele podobnych fragmentów, gdzie aktywność mimetycznaprzemiana w kogoś innego, podwojenie - staje się podstawowym mechanizmem postępu wszelkiej wiedzy i przeobrażenia rzeczywistości. Przypominam ponadto, że dialog filozoficzny to forma udramatyzowanego przedstawienia mimetycznego, całkowicie zgodnie z Sokratesowskimi definicjami odrzucającymi mimesis, dialog filozoficzny to także forma wymyślona przez Platona, by móc się stać kimś innym i wcielać się $w$ innych. W następnym rozdziale powrócę do paru przykładów tego rodzaju mimesis w praktyce pisarskiej Platona, wpierw jednak wskażę kilka fragmentów, gdzie mimesis pojawia się jako określenie pozytywne lub też jako fundamentalna zasada.

Po pierwsze, w Kratylosie, gdzie Sokrates z towarzyszami w sposób zaskakujący spekulują na temat natury języka i nadawania nazw. Sokrates nie potrafi przemóc się, by zaakceptować to, co problematyzuje każda praktyka i teoria mimetyczna, mianowicie konwencjonalny charakter języka i arbitralność znaków językowych w stosunku do sfery referencji. Zamiast tego, twierdzi Sokrates, postulować należy „naturalną" relację między znakiem językowym a określaną przezeń sferą referencji, nazwa należeć winna do rzeczy „zgodnie z natura” $\left(390^{\mathrm{e}}\right)^{11}$. Imieniem owej natury jest podobieństwo, znak językowy zatem wykazuje swą przynależ-

"Kratylos nie został przełożony na język szwedzki, korzystam więc $\mathrm{z}$ angielskiego tłumaczenia H. N. F o w le r a w serii „The Loeb Classical Library” (P l a to, Cratylus. W: Plato in twelve volumes. T. 4: Cratylus, Parmenides, Greater Hippias, Lesser Hippias. Cambridge, Mass., 1926). 
ność do natury poprzez imitację-naśladownictwo sfery referencji. Nazwę, słowo Sokrates opisuje jako ,naśladowanie za pomocą głosu tego, co naśladujący naśladuje i nazywa, kiedy naśladuje za pomocą głosu" $\left(423^{\mathrm{b}}\right)$. Aby zaś nie powstały żadne wątpliwości co do mimetycznego charakteru języka, Sokrates używa w owej replice czterech wariantów słowa ,mimesis”, a ponadto dodaje, iż tworzący język „,nazwodawca” jest tym, który wie, jak „,naśladować [...] »istotę« każdej rzeczy literami i sylabami" (423 e) (ciekawe zaiste, jak też wygląda ta naturalna aktywność, do której słowo „mimesis" podobne jest pod względem fonologicznym i ortograficznym).

Mimo to powstają wątpliwości, czy słowa nie są obciążone czynnikami przypadkowymi i arbitralnymi. Po części dlatego, że Sokrates dla podbudowania swej tezy o mimetycznym charakterze języka prezentuje zadziwiające (i arbitralne) fantazje etymologiczne, lecz także dlatego, że jego partner w rozmowie, Kratylos, przez swój opór najwyraźniej prowokuje Sokratesa do stawiania takich tez. Opór zaś polega na tym, iż Kratylos łączy mistykę nazw i języka z heraklitejskim wyznaniem wiary w ruch i ruchliwość, czyli w coś, czego Sokrates nie może zaakceptować. W tym miejscu w dialogu prześwituje problem klasyczny w filozofii greckiej już w dobie Platona - czas, zmienność i ruch oraz związek między mimesis a ruchem. Wydaje się, że związek ma jednak charakter negatywny, ponieważ Sokrates lansuje swe mimetyczne spekulacje na temat języka przeciwstawiając je raczej filozofii ruchu, którą dziś nazwać byśmy mogli np. konwencjonalizmem.

W Timajosie, wielkiej opowieści na temat stworzenia świata, Platon każe tytułowemu protagoniście zmierzyć się z relacją obraz/odbicie - czas i dzieje się to w obecności raczej tylko słuchającego Sokratesa. Teraz jako mimetyczne jawią się i opowiadanie, jak w Państwie, i polityka, jak w Prawach, i język, jak w Kratylosie, a mimesis staje się, ni mniej ni więcej, tylko zasadą stworzenia świata i jego forma. Timajos oświadcza, iż świat, w którym żyjemy, stworzony jest na najwierniejsze z możliwych podobieństwo do samego stwórcy (29 E-30 E). Metaforyka w tej opowieści filozoficznej ma charakter wybitnie wizualny, jak to się często zdarza u Platona, i sprawia wrażenie, jakoby stwórca był artystą co porównać można $z$ inną jeszcze słynną przypowieścią wizyjno-wizualną: rozdziałem o pieczarze w ks. VII Państwa, gdzie wykształcenie filozoficzne przyrównuje się do oka zdolnego znosić światło, a nawet spoglądać w samo słońce. Oznacza to możliwość oglądu niewidocznego bytu. Sokrates zwraca przy tej okazji uwagę, iż zdolność widzenia jest „obrazem (imitacja)” filozoficzno-dialektycznego procesu edukacji (532 A), równie dobrze moglibyśmy powiedzieć, że Platońska wizja filozofii została przekalkowana na zmysł wzroku czy też przynajmniej zorientowana wizualnie. Równocześnie preferuje się mowę i dialog jako formy komunikacji. Chwiejna zawartość Platońskiej mimesis ilustruje owo przeciąganie liny między fakultetami wzroku i głosu, trzykrotne wygnanie poetów interpretować można jako obronę prymatu mowy i wydanie swego rodzaju zakazu obrazowania. Zaraźliwa mimesis jednak nie pozwala się wygnać i staje się w Timajosie zwycięską zasadą jak zauważa Else - „widzenie przezwyciężyło w końcu mowę, myślenie i argumentację"12.

Kiedy Timajos orzeka, iż akt stworzenia świata nastapił zgodnie z zasadą podobieństwa, natrafia wkrótce na problem logiczny - sposób istnienia czasu. Za-

12 E 1 s e, Plato and Aristotle on Poetry, s. 61. 
kłada się, że odzwierciedlony prapoczątek jest stały i niezmienny, podczas gdy obraz, czyli nasz świat, to najwyraźniej zmienny ,flux" w reżyserii czasu. Timajos powiada zatem, że stwórca, niestety, nie był zdolny do uczynienia obrazu/świata wiecznym i niezmiennym. Wszystko po to tylko, by później skonstatować, iż stworzony świat nosi w sobie ślad wieczności jako ,ruchomy obraz wieczności” (37 D). To, że gwiazdy powracają na swe trajektorie, jest dla Timajosa widocznym dowodem, iż „ten świat był jak najpodobniejszy do istoty żywej, która jest przedmiotem myśli, a jest doskonała - świat, który naśladuje jej naturę wieczną" (39 D, E).

Ustęp ten wart jest uwagi jako jedyny, jak sądzę, w którym Platon dyskutuje czas-przemianę-powrót w relacji do mimesis. Dyskusja ta staje się odtąd stałym elementem wszelkich sporów na temat mimesis, aż po ostatniego $\mathrm{z}$ ważniejszych filozofów zajmujących się tą kategoria, jakiego czytałem, mianowicie Paula Ricoeura, który uczynić chce $z$ niej pojęcie temporalne, zgodnie z zasada, iż „czas staje się czasem ludzkim w wymiarze, w którym wyrażony zostaje w sposób narracyjny; opowiadanie nabiera natomiast znaczenia, kiedy odzwierciedla przeżycia czasu"'3. Odnotować należy, że Platońska koncepcja z Timajosa w drodze do Ricoeura odwrócona została na wspak: opowiadanie mimetyczne jest dla Ricoeura obrazem/odbiciem ruchu, ,przeżycia czasu”, natomiast Timajos twierdził, iż czas odbija trwałą wieczność. Obu łączy jednak metaforyka: Timajos mówi o „podobieństwie” stworzenia do praprzyczyny, Ricoeur twierdzi, że opowiadanie „odzwierciedla" czas ${ }^{14}$.

Inny sposób interpretacji zawartości temporalnej Platońskiej mimesis demonstruje Martin Heidegger, podejmujący w Byciu i czasie osobliwą definicję czasu $\mathrm{z}$ Timajosa. Nie dzieje się to jednak z użyciem terminologii wizualnej, lecz jako próba ustalenia pewnej paradoksalnej cechy teraźniejszości, (,das Jetzt”), tego mianowicie, iż teraźniejszość jest wciąż zmienna, równocześnie jednak stale obec$\mathrm{na}^{15}$. Heidegger stwarza w ten sposób podwaliny dyskusji o czasie w kategoriach powrotu i powtórzenia (termin użyty przez Heideggera to „Wiederholung”), będącej także powtarzającym się elementem w niniejszej prezentacji, wpierw w następnym rozdziale, gdzie szkicuję repetytywną praksis Platona w kilku dialogach, dalej zaś w rozdziale kolejnym, gdzie zajmuję się Platońską krytyką repetycji Homerowej. Owa repetytywno-temporalna mimesis zaś po raz pierwszy zdefiniowana została w Timajosowym określeniu czasu, a po raz pierwszy zinterpretowana jako zjawisko czasowe w zacytowanym przykładzie (39 D) o gwiazdach poruszających się w powtarzających się powrotach, gdzie ruch jest, jak się wydaje, tożsamy z wiecznym ,teraz" czy też z wiecznym powrotem.

Platon skazuje poetów na wygnanie wyrażając w pewnym sensie ową ,utratę "ja«" zawartą w podwajaniu się, stawaniu się kimś innym, rozpływaniu się w obrazie. W ten sposób spekulowałem poprzednio na podstawie (chwiejnej) niespodziewanego, gwałtownego i pozbawionego w danym kontekście motywacji oskarżenia, które Platon każe skierować Sokratesowi przeciw imitującemu kuglarzowi, mimowi-naśladowcy. Reminiscencje tego rozumowania dostrzegliśmy również

13 P. R i c o e u r, Temps et récit I. Paris 1983, s. 17.

14 Trzeba tu podkreślić, iż „odzwierciedlenie" nie jest idealnym przekładem „, dessine les traits”, oddaje jednak przynajmniej aspekt wizualny terminu.

is M. H e i de g g e r, Bycie i czas. Przełożył, przedmową i przypisami opatrzył B. B a ra n. Warszawa 1994. Oryg. wyd. 1: 1927. 
w pełnym pogardy odrzuceniu przez ,nieznanego Ateńczyka” z Praw niskiej i kuglarskiej mimesis, którą przeznaczono „niewolnikom i obywatelom obcym, wynajętym", a więc tym, którzy żadnego ,ja" do stracenia nie mają (816 E). Kuglarza Platon traktuje ze wzgardliwą powagą, a powodem - paradoksalnie - jest chyba związek z mimesis, z zaraźliwym tworzeniem obrazów, zawsze zwyciężającym słowo filozofa ze względu na swą nadrzędność. W świecie Platona obraz wyprzedza słowo tak samo jak idea, forma i byt wyprzedzają świat fenomenalny. Dialektyka Platońska prowadzi walkę przeciw owemu pierwszeństwu, walkę beznadziejnă, ponieważ słowo filozoficzne w poszukiwaniu samego ideału napotyka jedynie ideał jako obraz i jako obraz/odzwierciedlenie idei. Mimesis mimo trzykrotnego jej wygnania wciąż jest obecna jako obraz i odzwierciedlenie.

Świat fenomenalny to także świat ruchu, czasu i przemijania, odzwierciedlająca aktywność mimetyczna jest nierozerwalnie złączona z powtórzeniem, zatem $\mathrm{z}$ czasem. Platon prowadzi walkę z czasem, w którym utrata ,ja" zwie się śmiercią zarówno wtedy, gdy skazuje aktywność mimetyczną na wygnanie $\mathrm{z}$ idealnego państwa, jak i wtedy, gdy (w Timajosie) chwala ją jako niezmienną formę i zasadę kreacji. Walka Platona $z$ czasem to projekt pozbawiony nadziei, w tym znaczeniu Platon nie jest tak bardzo odległy od bohaterów Homerowych, których poza tym każe krytykować Sokratesowi w Państwie. Bohater epicki dąży zawsze do przezwyciężenia śmierci, jego właściwy wróg zwie się dlatego Kronos. Już Zeus wiedział od chwili, kiedy udało mu się strącić swego ojca Kronosa, by samemu uczynić się olimpijskim ojcem, że chytrość znaczy w owej walce tyle samo co odwaga. Czasu nie można zwyciężyć, ale można nim manipulować. Platoński wariant owej chytrej manipulacji polega zaś na stworzeniu formy opowiadania, która zarazem nie jest opowiadaniem: dialogu filozoficznego. Forma ta konstytuuje/na-nowo-powtarza czas miniony w opowiadanym „teraz”: konstrukcja mimetyczna zbudowana tak chytrze, że w pełni pozwala na krytykę mimesis.

\section{Dialog}

Nieśmiertelność, uczy nas Platon, jest także celem miłości. Pod warunkiem, oczywiście, że uda jej się oderwać się od rzeczy przypadkowych, codzienności, przemijalności, rozkładu, od wszystkiego, co przynależy do życia cielesnego - po to, by miast tego poszukiwać dobra. Miłość Platońska poszukuje właśnie dobra, z czego zaś nieuchronnie, jak twierdzi filozof, wynika, że dąży ona także do nieśmiertelności. Taki przynajmniej jest wniosek końcowy w Uczcie - słynnym dialogu na temat miłości:

A przecież, wobec tego, na cośmy się zgodzili, musi człowiek i nieśmiertelności pragnąć, jeżeli przedmiotem miłości jest w i e c z n e posiadanie dobra. Więc wynika to rzeczywiście z naszych rozważań, że się Eros i do nieśmiertelności odnosi. [207A; podkreśl. A. M.]

Tak sformułowany został znany logos Platona. Jak jednak sprawa przedstawia się z jego leksis, w jaki sposób do niej docieramy? I kto właściwie wygłasza ów wniosek? Tak bowiem brzmi podstawowe pytanie we wszelkiej narratologii wywodzącej się z mimesis Platona: kto mówi? Gdy wkłada on w usta Sokratesa owo pytanie w ks. III Państw'a, stwarza podwaliny narratologii; punktem wyjścia jest spostrzeżenie, że Homer każe postaciom z Iliady przemawiać swoim głosem i że 
mimesis zdefiniować można właśnie jako nadawanie głosu innym i innemu: jako zdolność poety do przemawiania jak ktoś inny. Narratologia jest zatem nauką opierająca się na rozróżnieniu „,co” od ,jak” opowiadanego tekstu, czyli bada ona relacje między fabułą a intrygą, wraz ze wszystkimi rysami i pęknięciami, które nieuchronnie powstają między nimi. W owych nieuchronnych pęknięciach usłyszeć można głos, odczuć wzrok, tam toczy się czas. Głos i wzrok, ponieważ głos i wzrok opowiadacza nigdy nie mogą zostać przekazane bezpośrednio, lecz docierają do nas w sposób pośredni, za pośrednictwem postaci i świata przedstawionego w opowieści. Czas, gdyż opowieść ma przebieg czasowy lub zakłada jego istnienie, zatem jest on kształtowany w czasie opowiadania, poprzez figury opowieści. Każda strategia mimetyczna opierająca się na zasadzie podobieństwa a tak dzieje się zawsze w mimesis Platońskiej - musi uporać się z zadaniem uczynienia głosu i wzroku opowiadacza podobnymi do in ne go (a głosu i wzroku i n n e g o podobnymi do opowiadacza) i z upodobnieniem w jakimś sensie czasu fabuły do czasu intrygi.

Strategia Platona to, jak wiadomo, dialog filozoficzny. Głos w nim otrzymuje Sokrates i jego partnerzy w rozmowie. Relacja między Platonem a Sokratesem stała się przez to tematem zażartych dyskusji badaczy, bo w żaden sposób nie da się rozwiązać kwestii rozgraniczenia głosu Platona od głosu Sokratesa. $\mathrm{Z}$ punktu widzenia narratologii łatwo jednak stwierdzić, że Platon zachowuje się mimetycznie - podług recepty, którą kazał wykląć Sokratesowi w ks. III Państwa - i sam obdarzył siebie głosem kogoś innego czy też innych (alternatywnie obdarzył innych własnym głosem). Zacytowany przed chwilą wniosek o związku miłość-dobro-nieśmiertelność sformułowany wszakże zostaje nie przez samego Platona, ale przez Sokratesa, czyli Platon każe w sposób mimetyczny sformułować wniosek Sokratesowi.

A jednak nie. Sam Sokrates cytuje bowiem pewną kobietę, która w swoim czasie uczyła go miłości, niejaką Diotymę. Wybiera formę dialogu w dialogu, a ów dialog mieszczący się $w$ ramie innego, zawierający także zacytowany wniosek końcowy całego dialogu, wprowadzony zostaje w sposób „diegetyczny”; znaczy to, że Sokrates streszcza zaistniałą sytuację (a więc opowieść o spotkaniu z Diotyma) podług przepisu, którego używa w ks. III Państwa (mówiąc ściślej, którego Platon każe mu użyć), by skorygować Homera. Nie trwa to jednak długo. Platon każe skonstatować Sokratesowi (wbrew sobie? lub też przez ,slip-of-the-tongue"? ale czyjego języka?), że mimesis jest wygodniejsza w użyciu od diegesis: „Otóż myślę, że najłatwiej będzie przejść te rzeczy tak, jak ta niewiasta z dalekich stron ze mną je przechodziła pytaniami” (201 E). Sokrates przystępuje zatem do przedstawiania mimetycznego, które wciela dawno minione spotkanie z Diotymą w ,teraz" dialogu Platońskiego. Wniosek owego dialogu o istocie miłości wypowiada zaś Diotyma, tzn. Sokrates każe wypowiedzieć go Diotymie (tj. Platon każe Sokratesowi kazać wypowiedzieć Diotymie wniosek).

Zawarty w ramach dialogu dialog między Sokratesem a Diotymą mieścił się w słynnym dialogu biesiadnym na cześć tragika Agatona, gdzie m.in. komediopisarz Arystofanes wygłasza apoteozę miłości, zanim do głosu dojdzie Sokrates (tzn. Platon każe dojść mu do głosu), by odtworzyć przemówienie Diotymy. Przypomina nam się przy tym dyskretnie, że Sokrates sumarycznie oddaje jedną lub kilka rozmów, które odbyły się dawno temu, kiedy np. bezpośrednio po wniosku mówi 
(tj. Platon każe mu powiedzieć), iż uczył się tego, ,ile razy [...] [z nim] mówiła o miłości" (207 A) ${ }^{16}$. Sokrates czyni (tzn. Platon każe Sokratesowi uczynić) więc z Diotymą to, co - jak wyobrażamy sobie - Platon uczynił z Sokratesem: w dialogu filozoficznym streszcza dawno minione rozmowy.

To zaś oznacza, że także dialog Platona o biesiadzie u Agatona jest stylizowany oraz - na przekór wszelkiej żywej, mimetycznej obecności - przywołuje przeszłość i wkracza w nią, czyli opiera się na napięciu między czasem/czasami fabuły a temporalną organizacją intrygi, zatem na napięciu między logos a leksis.

Kiedy Platon formułuje wniosek filozoficzny w odległym w czasie, ale oddanym mimetycznie w dialogu, podkreśla w ten sposób, jak mi się wydaje, właśnie owo napięcie temporalne. We wniosku łączy miłość $z$ nieśmiertelnością, tj. $z$ ustaniem czasu. Ów wniosek sformułować jednak można tylko poprzez stworzenie dystansu temporalnego oznaczającego całkowite zrelatywizowanie czasu. Kreowanie kolejnych opowieści ramowych stwarzających dystans nie kończy się bowiem na tym, że Platon każe wypowiedzieć swoje kwestie Sokratesowi, a ten z kolei każe wypowiedzieć swoje (lub/i Platona) Diotymie. Rama zewnętrzna (biesiada u Agatona) otaczająca ramę wewnętrzną (dialog Diotymy) jest też zawarta w konstrukcji ramowej. Cały dialog o biesiadzie odtwarza przecież (mimetycznie) niejaki Apollodor, któremu z kolei streścił go (nie wiemy jak) niejaki Arystodem, a ten (w przeciwieństwie do Apollodora) wziął udział w biesiadzie (według Platona). Innymi słowy - wniosek o miłości i nieśmiertelności sformułowany przez kobietę imieniem Diotyma dociera do nas za pośrednictwem czterech streszczających go mężczyzn: Sokratesa, Arystodema, Apollodora, Platona. Jej wniosek otaczają ponadto dwie opowieści ramowe: opowieść o Apollodorze, który napotyka nieznanego przyjaciela pragnącego usłyszeć coś o słynnej biesiadzie, oraz opowieść o biesiadzie - być może, pojawia się jeszcze aluzja do trzeciej instancji pośredniej w opowieści o Arystodemie, ten zaś (według jego własnych słów) milczy podczas całej biesiady, ale później staje się tym bardziej rozmowny (to przecież jego opowieść oddaje Apollodor).

Poszczególne poziomy opowiadania (całego opowiadania) zaznacza się w sposób będący czymś w rodzaju ironicznego podważenia wiarygodności mimetycznej na każdym z poziomów. Zacytowałem już, w jaki sposób Sokrates (tj. Platon, który każe wypowiadać się Sokratesowi) rozpoczyna dialog z Diotymą twierdzeniem, że będzie oddawał ,te rzeczy tak, jak ta niewiasta z dalekich stron [...] [z nim] je przechodziła pytaniami" (201 E), a kończy dementując owo postanowienie, kiedy przekazuje nam, że w istocie streścił tylko to, czego Diotyma uczyła go, ,ile razy [...] [z nim] mówiła o miłości" (207 A). Ponadto rozdział z obszernym przemówieniem Sokratesa zawierającym dialog z Diotymą, zainicjowany w ten sposób, że opowiadacz Apollodor przypomina o swej obecności (Platon każe przypomnieć o tym Apollodorowi) przez objaśnienie nieznanemu przyjacielowi, iż Sokrates rozpoczął ,stąd jakoś 〈mniej więcej tak〉” (199 C) ${ }^{17}$. Mniej więcej! Kwestie dialogu oddane są zatem w przybliżeniu. Oczywiście, jeśli Apollodora nie zawodzi pamięć. I jeśli wcześniej nie zawiodła pamięć Arystodema. Platon nie może się

${ }^{16} \mathrm{Z}$ przekładu Lindskoga nie wynika, iż z kilku spotkań Sokrates czyni jedno.

17 „Mniej więcej” nie odnajdziemy w przekładzie Lindskoga, pojawia się za to w innym tłumaczeniu szwedzkim, E. Westers. 
powstrzymać od zwrócenia uwagi czytelników na wszystkie owe momenty niepewności, np. kiedy podczas biesiady mowa o miłości rozpoczyna się od tego, że Apollodor przypomina sobie (Platon każe przypomnieć sobie Apollodorowi), że „Wszystkiego, co który powiedział, ani Arystodemos dobrze nie pamiętał, ani ja sobie nie przypominam wszystkiego, co mi mówił" (178 A). Apollodor obiecuje natomiast, że przekaże wybór tego, co podług niego „warto pamiętać” (178 A). Warto pamiętać!

Czy jednak naprawdę możemy zaufać owemu wartościowaniu dokonanemu przez Appollodora? Platon w każdym razie nie potrafił oprzeć się pokusie, by podać w wątpliwość jego prawdomówność. Na samym początku całej opowieści dowiadujemy się przecież, że Apollodor jest awanturnikiem, którego powszechnie nazywa się ,wariatem [manikos]" $(173 \mathrm{D})^{18}$ - co skłonić nas powinno do zakwestionowania każdego wypowiedzianego przezeń słowa, $\mathrm{tj}$. całej opowieści poza pierwszą ramą. Zakładając, rzecz jasna, że uwierzymy w ową złośliwą charakterystykę. Co nie jest oczywiste, wypowiada ją bowiem nieznany przyjaciel-słuchacz, o nim zaś dowiadujemy się od Apollodora, iż zwykł był zadawać się raczej z ludźmi prowadzącymi ,rozmowy o pieniądzach i interesach" $(173 \mathrm{C})$ niż z filozofami - trudno przyjąć to za oznakę solidności w świecie Sokratesa i Platona.

Wszystkie te dyskretnie ironiczne napomknienia o kolejnych poziomach tekstu i o napięciach między fabułą a intrygą przypominają o przesunięciach temporalnych $\mathrm{m}$ i ę d z y poziomami, przyczyniających się do zagęszczenia czasu n a poszczególnych poziomach i w każdym z nich. W ten sposób tworzy się w opowieści rytm zupełnie różny od sekwencji początek-środek-koniec, zalecanej przez Arystotelesa w Poetyce jako standardowa krzywa opowiadania, przesunięcia poziomów wprowadzają zamiast niej swego rodzaju podział staccato między bliskością a dystansem. Stosunek poszczególnych poziomów wobec siebie - jako ramowych opowieści w opowieści - opiera się zarazem na zasadzie powtórzenia: Apollodor powtarza Arystodema, który powtarza Sokratesa, ten zaś powtarza Diotymę. Obie manipulacje czasowe: staccato i powtórzenie, poprzedza efektywne preludium w otwarciu dialogu, gdy Apollodor już na wstępie oznajmia, iż nauczył się na pamięć (zob. 172) ${ }^{19}$ historyjki, jaką przytoczy. Opowiedział ją bowiem już innemu przyjacielowi, Glaukonowi, którego wyobrażenia o tym, kiedy właściwie odbyła się słynna biesiada, są nader zagmatwane. Wydawało mu się, że miała miejsce w ostatnich dniach, czyli niedawno, Agaton jednak, na jego cześć ją wydano, otrzymał swą nagrodę tragiczną wiele lat temu (,jeszcze jakeśmy dziećmi byli", 173 A), a więc w czasie tak odległym, że już niemal mitycznym. Opowieść, której wyuczył się Apollodor (reżyserowany przez Platona) ma potem uczynić bliskim to, co jest odległe dla nieznanego przyjaciela i dla nas.

Uczta nie kończy się mową Sokratesa zawierającą wniosek Diotymy o istocie miłości, lecz wkroczeniem nieproszonego i pijanego już gościa, Alcybiadesa, wygłaszającego mowę na cześć Sokratesa. Wpierw wydaje się, że Alcybiades ironizuje na temat Sokratesa tak bardzo jak Platon (narratologicznie) na temat całej biesiady, dowiadujemy się (tzn. Platon każe Apollodorowi przypomnieć sobie, że

${ }^{18}$ Linskog thumaczy „manikos” jako „skromny” (!), Westers - „w szale”. Przekłady angielskie oscylują między „crazy" a ,fanatic".

19 „Na pamięć” zniknęło z obu przekładów szwedzkich, a także z polskiego. [Przypis thum.] 
Arystodem przypomniał sobie, iż Alcybiades poinformował nas), że Sokratesowi bynajmniej nie można wierzyć i ufać (zob. 214 D), ponieważ „on całe życie z ludzi podrwiwa i żartuje z nich sobie" (126 E), ów wstęp przechodzi jednak w stusznie wychwalane przemówienie wysławiające oryginała Sokratesa: ,ale takiego oryginała, jak ten człowiek i jego mowy, ze światłem nikt nie znajdzie ani pośród współczesnych, ani dawnych postaci" (221 D). Po czym uczestnicy biesiady popadaja w powszechne pijaństwo. Platon każe Apollodorowi przypomnieć sobie, jak Arystodem przypomniał sobie, iż zasnął, a przebudziwszy się, ponownie usłyszał Sokratesa wciąż jeszcze kłócącego się z Agatonem i Arystofanesem. Zastrzeżenia są jednak znaczące:

Wszystkiego, o co tam szło, Arystodemos już nie pamiętał, bo od początku rozmowy nie słyszał i ciagle się kiwał drzemiąc. To jednak była główna treść dialogu, że im Sokrates dowodzil, jako iż jest rzeczą jednego i tego samego twórcy umieć i tragedię napisać, i komedię ułożyć, i że kto jest artystą w tragedii, ten i komediopisarzem być potrafi. [223 D]

Ale o co w istocie chodziło w owym zakończeniu, w którym Platon kazał przypomnieć sobie Apollodorowi, że przypominał je sobie, być może w półśnie, Arystodem? Pointa jest, jak już wcześniej wspomniałem, zastanawiająca, wyraża bowiem coś zupełnie przeciwnego niż teza z Państwa wygłoszona przez Sokratesa, zgodnie z którą nikt nie może być równie dobry we wszystkim, co robi: „w dwóch pozornie bardzo bliskich rolach nie potrafi jeden i ten sam człowiek dobrze występować, na przykład pisać komedie i tragedie" (395 A). Pod koniec Uczty odnaleźć można jeszcze inny element przeciwstawny poetyce i estetyce sformułowanej w Państwie, mianowicie postać Alcybiadesa. To, że jego ingerencja w biesiadowanie tak nas urzeka, związane jest zapewne $\mathrm{z}$ demonstrowaną przezeń bezczelnością. Bezczelność ta przesądza jednak, iż jest on wszystkim, tylko nie owym wzniosłym i wzorcowym charakterem, który - jak to ujęto w Państwie - ewentualnie byłby wart wysiłku mimetycznego, raczej przypomina owo „usposobienie skłonne do wybuchów i raz takie, a raz inne" (605 A), ganione przez Sokratesa w Państwie. Na podstawie przekazów historycznych wiadomo, że Alcybiades nie był wzorcem godnym naśladowania: w czasie intrygi miał opinię rozwiązłego fircyka, w czasie tekstu - Platon napisał go około 30 lat po zdarzeniach historycznych - pozostawał niemal zapomniany i uznany za zdrajcę.

W zasadzie nie ma możliwości rozwiązania tych kontradykcji na poziomie filozoficznym, tezy Państwa wykluczają bowiem tezy Uczty. Jedyną inną ewentualnością wobec uznania Platona za myśliciela marnego i niekonsekwentnego wydaje się przyjęcie, iż jest on opowiadaczem i poetą. Nie oznacza to, oczywiście, że wymóg konsekwencji nie obowiązuje w tekście poetyckim, ale jedynie w filozoficznym. Wymóg ten stosować jednak trzeba na innym poziomie, odnieść raczej do j a k tekstu (leksis) niż do jego c o (logos). Ponadto chodzi tu bardziej (lub w tym samym stopniu) o praksis mimetyczną Platona, nie zaś o jego wizję pojęcia mimesis.

Logikę narracyjną, którą próbowałem wykazać w dialogu Uczta (tj. w odniesieniu dla Platońskiej praktyki mimetycznej), określić można, jak sądzę, mianem opowiadania z zastrzeżeniami. Tekst zanieczyszczają liczne mniej lub bardziej ironiczne zastrzeżenia, nagromadzone przede wszystkim w konstrukcji ramowej wokół trzech opowieści zawartych w tekście i w nich samych (tj. Apollodor i jego „nieznany” przyjaciel, biesiada u Agatona, Sokrates i Diotyma). Zarazem mamy 
do czynienia z opowiadaniem z uskokami; mimetyczna inscenizacja tekstu, pełna ciągle zmieniających się głosów, oznacza, iż słowa przechodzą z jednego rozmówcy na drugiego na poziomie mimetycznym, lecz także diegetycznym, że pomiędzy głosem a tekstem znajduje się kilka (do czterech) opowieści pośrednich. Zastrzeżenia i przesunięcia oznaczają ciagłe przemiany z obecności na dystans czasowy, są też zaczątkiem podwajającego powtórzenia między poziomami diegesis: opowieść Platona składa się z tego, co Apollodor już opowiedział, a co przed nim opowiedział już Arystodem o tym, co Sokrates już opowiedział o tym, co Diotyma już opowiedziała.

Mimesis jest, Platon każe o tym przypomnieć Sokratesowi w Państwie, trudnym do stosowania narkotykiem (,pharmakon", np. 382 C, D). W Uczcie Platon używa owego rozkosznego środka aż do zupełnego niemal odurzenia, co zresztą można uznać za mimetycznie uzasadnione w opowieści o biesiadzie. Inaczej ma się rzecz w Państwie, jak zresztą przystało na opowieść o prawidłowej organizacji państwa. Umiarkowanie przejawione w Państwie nie skłania, co prawda, do zakazu tworzenia obrazów, ale polega na tym, że Platon udziela Sokratesowi głosu w pierwszej osobie, bez szkatułkowych opowieści i pośredniczących, komplikujących oraz ironizujących głosów. Być może, to po prostu właśnie w różnicy narratologicznej między Państwem a Uczta leży przyczyna tego, że Sokrates w Państwie osądza ową mieszankę stylistyczną, za którą w końcu opowiada się w Uczcie. W Uczcie Platon zaprasza na narracyjną biesiadę, na mixed party ze złożonymi pod każdym względem osobowościami, od szaleńca Apollodora do szarmanckiego Alcybiadesa $\mathrm{i}$ do najbardziej ze wszystkich skomplikowanej i najbardziej zamkniętej w ramach opowiadania Diotymy, będącej zarówno kobietą jak i mędrcem, rzecz u Platona wysoce nieprawdopodobna. Pomieszane głosy w czasie opowiedzianym będącym mieszanką „teraz”, „wczoraj” i „dawno, dawno temu”. Mimesis znaczy tu 'wymieszanie' i 'pomieszanie' w praksis Platońskiej. Trudno się zatem dziwić, że filozof na koniec każe Arystodemowi (w stanie budzącym mieszane uczucia) przywołać z pamięci (Apollodorowi zaś przypomnieć, że Arystodem przypominał sobie) argumentację Sokratesa na rzecz skrzyżowania wysokiej tragedii z niską komedią. Czyni to w obecności Agatona, będącego wyłącznie tragikiem, i Arystofanesa, będącego wyłącznie komikiem. Sokrates argumentuje za prawidłowym użyciem/wymieszaniem narkotyku w dialogu Platońskim.

Jak twierdzi w Uczcie Alcybiades w swej mowie na cześć Sokratesa, strawił on życie na tym, że ,z ludzi podrwiwa i żartuje z nich sobie” (216 E) ${ }^{20}$. Od iej zaś chwili lub też - mówiąc ściślej - od chwili kiedy Platon przedstawił Sokratesa jako ironistę (,eiron”) w akcji dialogicznej, jego charakter oraz „gra” fascynuje, zaskakuje i drażni nas, którym nie dane było usłyszeć go i którym pozostała tylko lektura. Kierkegaard rozzłościł się podczas czytania owego pierwszego ironisty ${ }^{21}$, ale sam stał się jego następcą w mimetycznej grze podobieństw i pseudonimów. Heidegger, o którym powiedzieć można wszystko, tylko nie to, że był ironistą,

20 Używam tu przekładu Westers.

${ }^{21}$ Dzieło S. K i e rk e ga arda O pojeciu ironii z nieustajacym odniesieniem do Sokratesa (Przełożyła i posłowiem opatrzyła A. D ja k ow ska. Wraszawa 1999) już w tytule wskazuje na sławnego ironistę, ponieważ „wraz z Sokratesem pojęcie ironii wkroczyło w świat”. 
sławi Sokratesa, bo ,jest najczystszym myślicielem Zachodu”, a z owej przykładnej ,czystości” wywodzi jego naczelną cnotę filozoficzną: „Dlatego niczego nie napisał" 22 .

Ową szlachetną cechę - niepisanie - można, rzecz jasna, tylko zanotować w piśmie: Heidegger uwikłał się zatem w paradoksy podobne do tych, które były udziałem Kierkegaarda, kiedy ten usiłował ironicznie zdystansować się wobec Sokratesa. Uwikłał się w nie już Platon w dialogach, w piśmie imitujących wypowiedzi oralne i mimetycznie dystansujących się wobec mimesis. I w które uwikłał się już Sokrates, sądząc po dialogach Platońskich, albowiem użyć musiał środków mimetycznych i sofistycznych, by zaznaczyć swój dystans w stosunku do mimetyków i sofistów. Tego rodzaju paradoksy leżą, być może, u samych podstaw tego, co nazywamy myśleniem okcydentalnym, lub też myślenie owo składa się - by użyć tu słów Jacques'a Derridy - z „monumentów pojęciowych" ${ }^{23}$ ku czci płynnych przejść i rozróżnień między podobieństwami a różnicami. W słowie „,monument" mieści się po części także znaczenie 'grobowiec'; percepcja, myślenie i twórczość są zawsze ruchliwe, żywe i płynne, podczas gdy pojęcia próbują utrwalać i petryfikować jakiś stan rzeczy.

Na pewno mimesis jest tego rodzaju „monumentem”. Pojęcie to zajmuje w tradycji Zachodu miejsce, by tak rzec, monumentalne, zarazem jednak zawiera - czy też kryje w sobie - aktywny i twórczy paradoks. Kiedy Platon każe Sokratesowi zdefiniować pojęcie negatywnie, zarazem wciela je pozytywnie w życie, mamy do czynienia zarówno z ,monumentem”, jak i z paradoksem. Jednocześnie. Kiedy zaś w tym samym dialogu mimesis kojarzona jest $\mathrm{z}$ narkotykiem (,,pharmakon", np. 382 C) - pojęcie staje się już płynne. Podobnej terminologii farmaceutycznej używa Platon w dialogu Fajdros w związku z krytyką pisma, za pomoca takiej samej płynnej argumentacji każe Sokratesowi rozprawić się z sofistami i retorami w Fajdrosie, a także w Gorgiaszu i Protagorasie. Derrida w La Pharmacie de Platon raz na zawsze ustalił związek między Platońskim pharmakon a poglądami tego filozofa na pismo, tak jak zostały sformułowane w zakończeniu $F a j$ drosa. Pojęcie „pharmakon”, ledwo prześwitujące w tekście Fajdrosa (odnaleźć je można raz na początku $\langle 230 \mathrm{D}\rangle \mathrm{i}$ dwa razy podczas końcowej dyskusji na temat pisma $\langle 274 \mathrm{E}, 275 \mathrm{~A}\rangle$ ) ukazuje samo jądro wysiłku pojęciowego: próbę (negatywnego) uporządkowania pisma pod hasłem: pamięć/przypomnienie, kojarzy jednak również pismo z arbitralnością i grą albo igraszką (,paidia”, 276 B, 277 E). Pharmakon jawi się jako pojęcie nadzwyczaj płynne - ,płynna nieokreśloność” w terminologii Derridy ${ }^{24}$ - które zamiast (negatywnie) utwalić pojęcie „pismo”, otwiera je (pozytywnie) na grę zastąpień, powtórzeń, przesunięć i różnic. „Pharmakon to ruch, miejsce i gra (produkcja) różni [différance]" 25 .

22 M. He i d e g g e r, Co zwie się myśleniem? Przełożył J. M i z e r a. Warszawa 2000, s. 62.

23 J. De rri d a, La Pharmacie de Platon. W: La Dissémination. Paris 1972, s. 122

24 Ibidem, s. 105.

${ }^{25}$ Ibidem, s. 146. Trzeba tu zauważyć, iż Derridowskie odczytanie Platona wywołało niejedną polemikę: wyjątkowo krytyczną wypowiedź znajdziemy u S. R o s e n a w Platonic Reconstruction (w: Hermeneutics as Politics. Oxford 1987). Rosen twierdzi: „U Platona nie odnajdziemy metafizyki obecności" (s. 67), ponieważ nie ma tam żadnej ontologii. Nie istnieje też hierarchiczna różnica między mową a pismem, gdyż jedno i drugie jest sprzeczne z kategorią, której Derrida - zdaniem Rosena - nie toleruje, mianowicie ,silence”. Derrida ponadto ujmuje w nawias boskie szaleństwo (,mania”), a to - stwierdza Rosen - jest właściwym obiektem zainteresowania Platona w Fajdrosie. 
W Fajdrosie nie ma żadnej dyskusji na temat mimesis, lecz połączenie pharmakon z pismem jest uderzająco podobne do połączenia pharmakon z mimesis w Państwie; poczesne miejsce w Fajdrosie zajmuje inne pojęcie z poetyki Platońskiej, którego brak w trzeźwo osądzającej sztukę dyskusji w Państwie, mianowicie szaleństwo (,mania”). Platon każe Sokratesowi wygłosić dwie mowy o miłości: w pierwszej naśladuje on sofistyczną mania, by wygłosić tezę, w którą najwyraźniej sam nie wierzy; w drugiej natomiast mowie (tzw. palinodii) ogarnia go z kolei inspirująca mania, by mógł wyłożyć swe poglądy o miłości, prawdzie i pamięci. Także więc mania, podobnie jak graniczny termin ,entosiasmos”, potraktowany lekceważąco w dialogu Ion - to najwyraźniej pharmakon, które właściwie użyte prowadzi do lepszego wglądu w istotę rzeczy, przy złym dawkowaniu jednak - do najbardziej nagannych przeinaczeń. Pierwsza mowa Sokratesa winna być odrzucona, a znaczy to, iż jako dobry mimetyk naśladuje on argumentację sofistyczną, przeto (zgodnie z logiką Platońska) wartą odrzucenia.

Obie mowy, dialogicznie opozycyjne wobec siebie, ujęte są w ramy dowcipnego dialogu Sokratesa z Fajdrosem, którego młodość i piękno ten pierwszy (na niby?) podziwia. Innymi słowy: znajdujemy się w strukturze dramaturgicznej zupełnie odmiennej niż w Państwie, gdzie Sokrates wygłasza wykład przed grupa przyjaznych mu słuczaczy, albo w Uczcie, gdzie panuje dystans temporalny i polifoniczny szał. Fajdros zaprasza natomiast do teatru intymnego, który rozpoczyna się od tego, że Sokrates - jedyny raz - opuszcza miasto zwabiony rulonem pisma wystającym spod szaty Fajdrosa (nazywanym przez niego pharmakon! - zob. 230 D). Chce znaleźć się bez świadków w sielskim pejzażu, co najwyraźniej staje się inspiracją do wygłoszenia dwóch mów, zarówno nagannej, jak i budującej. Jesteśmy na niepewnym gruncie, poza zwykłym miejscem dialogu, czyli poza miastem, w swawolnej, erotycznej grze, w pobliżu inspiracji i szaleństwa. Podobnie jak w Uczcie, mamy tu do czynienia z opowiadaniem z zastrzeżeniami, dotyczą one jednak tym razem nie czasu i głosu, ale perspektywy i spojrzenia.

W obu przypadkach powstaje niepewność. W Fajdrosie niepewne jest przede wszystkim, w jaki sposób rozumieć końcową rozprawę $z$ pismem: czy to kolejne szaleństwo, czy też mówi się $z$ całkowitą powagą? W jaki wobec tego sposób rozumieć zdystansowanie się wobec pisma sformułowane na piśmie i w piśmie imitującym mowę podług mimetycznego przepisu, który Platon w Państwie każe odrzucić Sokratesowi? Jeśli wsłuchamy się uważnie w zakończenie dialogu, możemy - wraz z Elsem - ,odkryć, iż Platon z dyskretnym uśmiechem daje nam do zrozumienia, że jego dialogopisarstwo jest rodzajem gry" ${ }^{26}$, gra (,paidia") zaś to jedno $\mathrm{z}$ zaraźliwych słów dialogu. Jeśli ponadto spojrzymy na owo zakończenie w kontekście przesuwających perspektywę oglądu zastrzeżeń, do czego cały dia$\log$ (począwszy od tego, iż Fajdros za pomoca pisma zwabia Sokratesa poza miasto) zaprasza, trudno oprzeć się wrażeniu, że końcowe, wyzbyte cienia wątpliwo-

Odwołując się do innych przesłanek, za to samo oraz za pomysł o Platońskim „ojcobójstwie” Derridę krytykuje J. S v e n b r o w Phrasikleia. Anthropologie de la lecture en Grece ancienne (Paris 1988); wskazuje on, że głównym zagadnieniem w Fajdrosie pozostaje nie tyle krytyka pisma, co inspirujące Sokratesa pojęcie ,mania". Należy też dodać, że J. De r ri d a powraca do rozróżnienia mowapismo i do Platońskiego „ojcobójstwa” z pewną ironiczną krytyką w La Carte postale (Paris 1979).

${ }^{26} \mathrm{E} 1 \mathrm{~s}$ e, Plato and Aristotle on Poetry, s. 58. 
ści twierdzenia Sokratesa o piśmie i o pamięci są ironicznie wtrącone do tekstu także nie dającego jakiejkolwiek pewności, ale przeciwnie - będącego zaawansowaną grą paradoksami.

Przedmiotem owej gry są dusza, miłość, prawda i pamięć. Gra staje się najpoważniejsza - i najbardziej paradoksalna - kiedy Sokrates w drugiej mowie każe duszy wznieść się na skrzydłach miłości ku najgłębszej, esencjalnej istocie najwyższej prawdy, co Platon nazywa „ousia” (247 C). Paradoks polega na tym, iż nieustannie posługuje się on obrazami dla opisania przygód duszy, a tu wydaje zakaz przedstawiania owej „ousia” w obrazach. Nie można jej zobaczyć, jest oślepiająca, dotrzeć do niej pozwala tylko intelekt („episte”, 247 D). Dusza może następnie pamiętać lub przypominać sobie o ousia. Rzecz jasna, to filozof jest tym, który pamięta najdokładniej, podczas gdy poeta trafia dopiero na siódmą pozycję w sporządzonej przez Sokratesa klasyfikacji pamięci (zob. 248 D, E).

W Państwie, przypomnijmy, poetę oddzielały od prawdy trzy poziomy. Tu mamy ich sześć. W Prawach piękny wytwór powstały na podstawie poetyki znalazł się na tym samym poziomie co oparty na prawach wytwór polityki. W Timajosie zaś już stworzenie świata było mimetyczne, a świat stanowił obraz/odzwierciedlenie. W Fajdrosie to pismo zostało nazwane obrazem (,eidolon”, 276 A) i w zakończeniu krytykuje się je uznając za niepewne pharmakon, bardziej nadające się jako ostrzeżenie niż pamięć. Jednoznaczne odczytanie, skonstruowanie stabilnego Platońskiego monumentu pojęciowego ze wszystkich owych nie dających się pogodzić twierdzeń powinno być rzeczą niemożliwą; nie przeszkodziło to jednak rzeszom czytelników nie mogącym znieść niepewności stworzyć „,platonizm". O ile na poziomie pojęć brak konsekwencji, o tyle odnaleźć ją można na poziomie dialogicznym opowiadania Platońskiego: jawi się ono jako konsekwentna fantazja wizualna, gdzie tworzenie to obraz, poezja to obraz i pismo to obraz. Platon tworzył swe dialogi mimetycznie, pojęcia zaś, jak się wydaje, obrazowo. W Fajdrosie formułuje - on, który myśli obrazami - paradoks mimetyczny bodaj najbardziej wyraziście i dosadnie, kiedy w swej fantazji o źródle i prapoczątku, ousia, deklaruje, iż ta niedostępna jest dla wzroku.

W Uczcie znalazłem powody, by pytać o głos: kto właściwie mówi? W Fajdrosie próbowałem uchwycić spojrzenie. Dialog Platoński nie zapewnia jednak stabilności tym koniecznym do opowiadania narzędziom, podobnie jak Sokratesowska „musztra pojęciowa” nie daje w rezultacie jakiegoś ,platonizmu”. Dialogi Platońskie plasują natomiast czytelnika w wątpliwej pozycji, w której stawia się i sam Sokrates po tym, jak udzielił pouczenia Trazymachowi w ks. I Państwa: „I teraz mi tyle wyszło z rozmowy, że nic nie wiem” (354 C). Pozycję tę zaiste trudno nazwać „monumentalną”. Jeśli jednak ma coś wspólnego z ową nieśmiertelnością do której dążą i dusza, i miłość, jeśli wierzyć Fajdrosowi i Uczcie, to dlatego, iż zapraszają do dyskusji, która nigdy nie będzie miała końca.

\section{Repetycja Homerowa}

Platon skazał poetów na wygnanie.

Przede wszystkim zaś Homera, w Państwie zwanego zarówno przewodnikiem tragedii (598 D), jak i pierwszym z poetów (600 E), dostarczającego Sokratesowi wielu przykładów na naganne intrygi i wątpliwie skonstruowane fabuły. 
To, że dzieła Homera wykorzystane zostają jako argument w Platońskiej krytyce mimesis, nie jest zaskoczeniem: autor Odysei od dawna zajmował tak dominującą pozycję wśród poetów greckich, że imię jego stało się wręcz synonimem poety. Nie jest też zaskoczeniem, iż Platon większość przykładów zaczerpnął z Iliady, albowiem pełniła ona rolę eposu narodowego na długo przedtem, zanim Greków nazwano narodem. Dziwi natomiast poniekąd, że Platon, który czasem wydawał się konserwatywnym wielbicielem autorytetów, tak gwałtownie rzucił się na monumentalnego Homera: po części wytłumaczeniem może tu być owo rozdwojenie w stosunku do (i w samej) mimesis, które starałem się już wcześniej naszkicować. Być może, uda nam się zbliżyć nieco do owego paradoksalnego rozszczepienia rozpatrując kilka przykładów krytycznych, jakie Platon każe przedstawić Sokratesowi.

Jak pamiętamy, Platon/Sokrates na początku podejmuje treść opowieści, czyli ich „co”, następnie samo opowiadanie, czyli ,jak” opowieści. Dzieje się to w ks. II i III Państwa i jest podstawą do podsumowań oraz osądów wyrażanych najpierw w ks. III, potem zaś - z naciskiem - w ks. X. Mimesis wiąże się z oboma owymi aspektami, z treścią opowieści i ich wykonaniem (logos i leksis). Homera krytykuje się za to, iż portretuje bogów i herosów mniej boskimi i heroicznymi, niż są (lub winni być), w opinii Platona/Sokratesa, oraz za dramatyzację opowiadania mimetycznego. Pierwszy przykład na niewłaściwą treść wzięty jest z ostatniej księgi Iliady: to mowa Achillesa do Priama (przede wszystkim I XXIV 527532). W zasadzie jedyny przykład chybionego wykonania pochodzi z ks. I Iliady, mówiąc ściślej: jest to początkowy fragment, przejście od streszczenia (Platon/ Sokrates nazywa je „czystą" albo ,niezmąconą" diegesis) do opowiadania mimetycznego (,dia mimesis", 392 D) z bezpośrednimi przytoczeniami.

Początek i koniec Iliady łączą się i jest to często komentowana zależność. Także Platon, jak sądzę, zakłada istnienie owej zależności. Znaczy to, iż nie rozwija ani nie komentuje, co prawda, żadnych takich kontekstów, jako pierwszy przykład mimesis Homerowej wybiera jednak właśnie te dwa fragmenty wielkiego tekstu; są one nie tylko przykładami swego rodzaju mimesis, lecz także względem siebie znajdują się w pewnej relacji mimetycznej. Właśnie ta relacja mimetyczna - wstępnie nazwijmy ją powtórzeniem albo repetycją - jest owym wariantem mimesis, którego Platon nigdy nie komentuje, lecz za to go wykorzystuje w praktyce. Tak dzieje się w rozmaitym stopniu i w różnych wariantach w każdym tekście narracyjnym - przykłady wariacji Platońskich dałem już w analizie Uczty.

Repetytywny wariant Homerowy scharakteryzować też można jako odzwierciedlenie bądź kompozycję kolistą: ostatnia księga (lub jej fragmenty) Iliady jest odwrotnie symetryczna względem pierwszej. Widać to znakomicie na dwóch wybranych przez Platona/Sokratesa przykładach: kiedy Achilles przemawia w ostatniej księdze, chodzi o udzielenie pozytywnej odpowiedzi Priamowi przybywajacemu z okupem, by wymienić nań ciało swego syna Hektora. W ks. I zaś to kapłan Chryzes przemawia, aby w zamian za okup domagać się swej żyjącej, lecz uwięzionej córki. Jak wiadomo, negatywnej odpowiedzi Chryzesowi udziela Agamemnon, oznacza to zatem, że Achilles ,powtarza” Agamemnona, Priam - Chryzosa, martwy bohater - uwięzioną dziewczynę, przede wszystkim zaś pozytywna odpowiedź - negatywną. Repetycja to najczęściej powtórzenie tego, co ją poprzedza, lecz oznacza także odwrócenie; repetycja, by tak rzec, podejmuje i przezwycięża swe pochodzenie. 
Krytyka owego kluczowego fragmentu dokonana przez Platona/Sokratesa przenosi się następnie na bogów. Kiedy Achilles zwraca się z przemową do Priama, chce pocieszyć starca, że jego syn, Hektor, zostanie mu oddany. Rozpoczyna swą mowę od wygłoszenia kilku uwag na temat bogów, które Platon/Sokrates zacytuje (niezbyt dokładnie) jako przykład wyjątkowo głupich „błędów” (379 D) Homera. Przypomnijmy ów fragment:

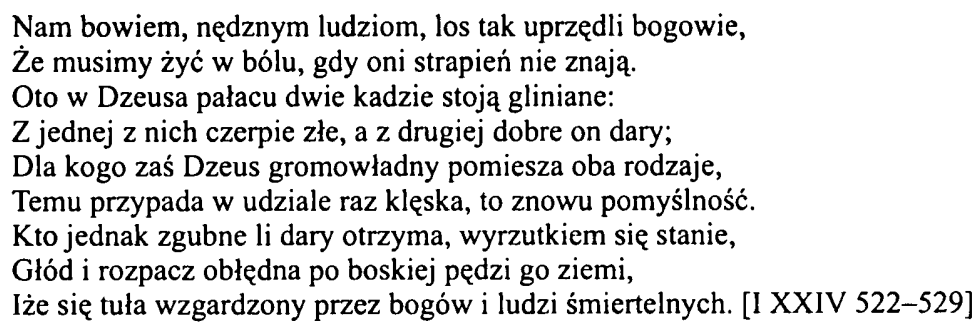

Na czym polegają - według Platona/Sokratesa - owe straszliwe ,błędy” popełniane przez Homera w tych wersach? Jak wynika $z$ kontekstu w Państwie, mogłoby chodzić o nieco fatalistyczny nastrój i wytknięcie szefowi bogów, Zeusowi, iż przynosi ludziom tyleż dobra, co zła. Czy może chodzić też o to, że mowa ma charakter powracającej repetycji? Nie zapomnijmy zatem, iż stanowi ona preludium do złagodzenia straszliwego gniewu Achillesa w ks. XXIV, a więc do zasadniczego tematu Iliady: pojednania Achillesa z Priamem, oznaczającego też chwilowe zawieszenie broni między Grekami a Trojanami - jednak Achilles kilka wersów dalej (I XXIV 540-541) zapowiada własną rychłą śmierć. Równocześnie w rzeczy samej podejmuje-powtarza-przezwycięża nie tylko choleryczne przemówienie Agamemnona z ks. I, ale i własną osobliwą mowę z ks. IX (w. 308-429). Także w niej Achilles przyjmuje wizytę, tym razem delegację Greków z Odyseuszem na czele, który darami i dobrym słowem przekonać ma Achillesa, by przystapił do walki. Ten stanowczo odpowiada „nie”, raczej powróci do domu. Jego argumentem jest śmierć, śmierć zaś to argument bardziej ważki niż honor:

Jedna nagroda, czy ktoś od bitwy stroni, czy walczy;

Mężny rycerz i tchórz tej samej czci zażywają

Śmierci ulega po równi mąż uznojony i nicpoń. [I IX 319-321]

Wydawać się może, iż Achilles rezygnuje tu $\mathrm{z}$ roli bohatera - wersu 320 nie powinien wypowiedzieć żaden bohater. Niektórzy znawcy języka twierdzili ponadto, że zacytowane tu wersy odbiegają od normalnej składni Homerowej i że Achilles w ten sposób, by tak rzec, usiłuje wyłamać się z języka heroicznego ${ }^{27}$. O dziwo, Platon/Sokrates nie przytacza tego fragmentu jako przykładu Homerowej pomyłki w sztuce mimetycznej, nie mam więc powodu, by zatrzymywać się przy nim, traktuję go jedynie jako podstawę do wprowadzenia elementów ukierunkowanych na powrót-repetytycję w ks. XXIV. Tam zaś umieścić trzeba topografię obu scen: jako jedyne w Iliadzie rozgrywają się nie na polu bitwy pod murami Troi ani w bardziej ,miejskim” środowisku wewnątrz murów, lecz w namiocie usytuowanym między morzem a Troją. Namiot jest miejscem ,ani-ani”,

${ }^{27}$ Zob. S. L. S c h e in, The Mortal Hero. An Introduction to Homer's ,"Iliad". Berkeley 1984, s. $91 \mathrm{n}$. 
w owych dwóch fragmentach Iliady bohater odpoczywa od bycia bohaterem, wojna na krótko przestaje być wojna. Ponadto nie panuje tu ani dzień, ani noc, sceny w namiocie rozgrywają się o zmierzchu, kończą się zaś w nocy ${ }^{28}$.

Za pomocą takiej sugestii Homer buduje repetycję ks. XXIV, jej aspekt ukierunkowany na podjęcie na nowo i przezwyciężenie. Mowa Achillesa, jego „błąd” - według Platona/Sokratesa - podejmuje na nowo ,ani-ani” ks. IX i przezwycięża antagonizm ks. I, jej ,albo-albo". W ten sposób dyskretnie detronizuje się bogów, a śmiertelnicy zapełniają całą scenę, wprowadzenie Achillesa zaznacza dystans i decydującą różnicę: bogowie są nieśmiertelni, mogą przeto czynić wszystko dla zabawy, podczas gdy losem człowieka śmiertelnego jest ,żyć w bólu” (I XXIV 522). Przez podkreślenie tego, co ogólnoludzkie, Achilles powtarza swą próbę wyrwania się $z$ roli herosa $\mathrm{z} \mathrm{ks}$. IX, tym razem udaje mu się to tak dalece, że jego gniew ustaje i epos bohaterski może dobiec końca. Zjada więc wspólny posiłek z Priamem, bez złożenia ofiar bogom, kończący się całkowitym pojednaniem - zdaje się, iż trojański patriarcha traktuje mordercę swych licznych synów jak nowego syna:

Gdy już żądzę napitku i jadła głód ukoili, Priam, Dardanów szczep, na Achilla w podziwie spozierał Jak był rosły i piękny, do bogów iście podobny. Zasię Priama, szczep Dardanowy, podziwial Achilles, Patrząc na postać szlachetną i słów tamtego słuchając. [I XXIV 626-630]

Spojrzenie człowieka - bez udziału bogów - staje się dopełnieniem powracająco-przezwyciężającej repetycji.

Na tę właśnie powracająco-powtarzającą mimesis Platon/Sokrates wskazuje swymi przykładami. Nigdy nie podejmuje jednak w sposób wyraźny dyskusji o zjawisku repetycji, odrzuca ponadto mimesis w sposób niewyraźny albo niespójny. Owa pominięta przez niego mimesis traktuje o obrazie, odzwierciedleniu, imitacji oraz o mimice, a nie o przesunięciu czasowym, które repetycja zakłada, by móc przezwyciężać poprzez podjęcie na nowo. Praksis mimetyczna Platona ma natomiast charakter w najwyższym stopniu repetytywny, dialogi filozoficzne, jak dało się zauważyć, pozostawiają wiele miejsca dla spojrzenia i głosu człowieka. Relacja Platona-pisarza do głosu Sokratesa wydaje się także repetytywna zarówno w sensie powrotu, jak i przezwyciężenia; być może, stanowi też powtórzenie owej relacji ojciec-syn, której idealizację i zharmonizowanie dostrzegliśmy w ostatnim cytacie z Homera.

Czy w jakiś sposób wprowadzić można jednoznaczność do tego splotu wieloznaczności? Znaleźć formułę zamykającą mimesis w jednym pojęciu i sytuującą w jednym miejscu? Czytelnicy Platona od stuleci gorliwie przemieniali wielogłosowość dialogów w jeden głos będący ,platonizmem”, czyli czymś, co - jak ośmielam się twierdzić - skazane jest na niepowodzenie. Chodzi jednak, rzecz jasna, o niepowodzenie konieczne, czytelnik zawsze musi podejmować próby znalezienia w dziele Platona i poza nim płaszczyzn i formuł objaśniających, by nie zagubić się $w$ paradoksach. $Z$ punktu widzenia mojej prezentacji nastawionej na problematyzowanie, do najciekawszych należą próby operujące przeciwieństwami, np. przeciwieństwem między poetą (Homerem) a filozofem (Platonem) albo mię-

${ }^{28}$ Zob. M. L. G e org e, Epos: Word, Narrative and the "Iliad". London 1988, s. 9-24. 
dzy słowem mówionym (Sokrates) a pisanym (Platon) lub też między kulturą oralną (Homer, Sokrates) a kulturą pisma (Platon). Czy atak na Homerową mimesis, który Platon każe podjąć Sokratesowi, nie jest wręcz etapem w przezwyciężaniu (starej) kultury oralnej przez (nowa) kulture pisma?

Tak przynajmniej z naciskiem twierdzi w serii książek, nade wszystko zaś w Preface to Plato, Eric A. Havelock. Opiera się przy tym na współczesnych interpretacjach (Parry, Lord) poezji Homerowej jako ustnej performance wykorzystującej repertuar formuł, stałych zwrotów, danych konstrukcji - co Havelock uogólnia jako tendencję oralną (,oral") lub Homerową (,Homeric state of mind"). Platońską krytykę mimesis Homerowej traktuje Havelock jako próbę usunięcia owej tradycyjnej/tradycjonalistycznej ,state of mind" ${ }^{29}$ na rzecz trybu przez Platona zwanego dialektycznym albo filozoficznym, przez Havelocka zaś analitycznym albo piśmiennym. Jednym słowem: Havelock konstruuje metapoziom, na którym interpretację Platońską wytłumaczyć można historycznie, a pewne niekonsekwencje rozwiązać i umieścić po przeciwnych stronach progu cywilizacyjno-historycznego. Jednocześnie dokonuje wielu ciekawych obserwacji tekstu zarówno Homerowego, jak i Platońskiego, np. kiedy powtórzenie uznaje za typowe dla tekstu Homera, antagonistyczne zaś wobec Platońskiego, co mogłoby stanowić wythumaczenie naszkicowanej przeze mnie wcześniej Platońskiej/Sokratesowskiej krytyki powtórzenia w Iliadzie.

Jeśli, rzecz jasna, chodziło o to samo powtórzenie. Havelock jednak, jak sądzę, nie odnosi się do omawianej przeze mnie repetycji, ukierunkowanej na przejmowanie-przezwyciężanie. Pojęcie repetycji u Havelocka oznacza natomiast aktywną identyfikację poety oralnego $\mathrm{z}$ tradycją-repertuarem i z poezją przywiązaną do formuł demonstrujących owo identyfikujące podporządkowanie się. Mój przykład wskazywał na co innego: postać Achillesa w wersji Homera wydaje się otwarcie krytyczna wobec tradycji zachowań bohaterskich, Homer podkreśla także w większym stopniu, niż wynikało to z tradycji, śmierć i i poczucie wspólnoty. Ponadto Homerowa repetycja ukierunkowana na przejmowanie-przezwyciężanie zwraca się raczej w stronę struktury i logiki narracyjnej niż formuł i repertuaru oralnego: tego, iż koniec Iliady powtarza jej początek $z$ elementami części środkowej (pod warunkiem, że ks. IX uważać będziemy za środek), w żaden sposób nie da się połączyć repetytywnymi formułami wiersza zgodnie z definicją formuły przyjętą przez Havelocka, a zwerbalizowaną przez Parry'ego: jest to ,grupa słów używanych regularnie w tych samych okolicznościach materialnych dla wyrażenia danej idei esencjalnej" 30 .

Nie mam, oczywiście, ani kompetencji, ani powodu, by oceniać całą tradycję badawczą na którą powołuje się Havelock, interesuje mnie wyłącznie Platońska mimesis widziana poprzez krytykę mimesis Homerowej. Muszę więc stwierdzić, że podział na ,pisemnego" Platona i „oralnego” Homera gubi istotę repetycji Homerowej, czyli to, co dla Platona/Sokratesa staje się punktem wyjścia do podjęcia krytyki Homera. Na pierwszy rzut oka rzeczywiście wydawać się może, iż Platon/ Sokrates bynajmniej nie krytykuje tradycjonalizmu Homera, lecz przeciwnie, jego przezwyciężanie tradycji przez repetycję. Jednocześnie, biorąc pod uwagę repety-

29 E. A. H a ve l o c k, Preface to Plato. Cambridge, Mass., 1963, s. 41.

30 M. P a r ry, The Making of Homeric Verse. Oxford 1971, s. 272. Wyd. 1: 1930. 
tywną praksis samego Platona, trudno przyjąć ową krytykę za dobrą monetę. Powstaje podejrzenie, że Platon każe Sokratesowi mówić co innego, niż on sam, Platon, ma na myśli. Ponieważ tego podejrzenia nie sposób zmienić w przekonanie, musimy zadowolić się ową miksturą repetycji oraz mimesis i pisma, ukrytą w szafie z truciznami Platońskiej poetyki: pharmakon, trucizna i lek zarazem, to pojęcie płynne i ulotne.

Ryzyko związane z prezentowaniem myśli Platona poprzez opozycje, np. pisemne-oralne, polega na tym, że w przeciwieństwie do niego samego staniemy się platonistami. Jeśli skojarzymy Platona z pismem, Homera zaś z oralnością by wraz z Parrym dojść do wniosku ,,iż jedna część literatury jest pisemna, druga oralna" ${ }^{31}$, napotkamy na trudności w wyjaśnianiu miejsc wspólnych, takich jak repetycja. Ponadto język jest systemem formuł i wzorców repetytywnych właśnie (żaden tekst literacki nie może abstrahować od owych przesłanek językowych); poezja zarówno w kulturach zdominowanych przez pismo, jak i przez słowo mówione zawsze opiera się na formułach i tworzy ich warianty.

Jeśli uznamy Platona za rycerza pisma, trudno nam będzie wyjaśnić kpiarskie ataki Platona/Sokratesa na pismo, podejmowane w Fajdrosie. Wreszcie ryzykujemy także idealizację kultury oralnej jako prapoczątku i Złotego Wieku, co ośmielam się nazwać platonizmem, nawet jeśli przeczy to Platońsko-Sokratesowskiej krytyce Homera.

Idealizacja zawsze zresztą wodziła na pokuszenie czytelników Homera, a gdy chodzi o dociekania, czym jest mimesis, powinienem wymienić jednego z najwnikliwszych: Ericha Auerbacha. Pierwszy rozdział jego pouczającej Mimesis (1946) rozwija opozycję między dwoma rodzajami przedstawienia (,Darstellung”) rzeczywistości. Przykładami są Homer (pieśń z Odysei) oraz starotestamentowa opowieść a Abrahamie i Izaaku (Rdz 22). Według Auerbacha przedstawienie Homerowe zawiera jedynie plan pierwszy, nic nie pozostaje nie opisane lub nie wypowiedziane, a zdarzenia postępują w prostej i kontrolowanej składniowo progresji. Historię biblijną cechuje natomiast komplikacja oraz to, co niewyrażalne, a obciążają mroczne tło i wymagające interpretacji wskazówki. Niezwykłe spostrzeżenia, które Auerbach czyni przywołując przykład Odysei Homera, nie zmieniają faktu, iż typizująca dychotomia między dwiema formami mimesis nakłada na tekst idealistyczny, „platoński” szablon. Mój szkic repetycji Homerowej powinien dostatecznie wykazać, że także Homer przyjmuje istnienie tła (np. morze-namiotmiasto), rozwija skomplikowane charaktery (Achilles) i eksperymentuje z repetytywnie opowiedzianym czasem.

Auerbach należy do kontynuatorów solidnej niemieckiej tradycji. Wzmiankuje Schillera podczas analizy Homera, a dychotomia Auerbacha to w rzeczy samej powtórzenie słynnego Schillerowskiego przeciwstawienia: poezja „naiwna” (antyczna) - poezja ,sentymentalna" (nowoczesna), będącego z kolei powtórzeniem niezliczonych prób odróżnienia np. starego od nowego, elementów oralnych od elementów pisma, eposu od powieści. Tego rodzaju ćwiczenia umysłowe zwą się dialektyką, dialektyka zaś była właśnie, jak wiadomo, zalecanym przez Platona sposobem myślenia. Kiedy Havelock wywodzi dialektykę Platońską z kultury pisma i przeciwstawia ją Homerowej tradycji oralnej, popełnia ,platonizm” pod wzglę-

\footnotetext{
31 Ibidem, s. 377.
} 
dem formy nie tak odległy od tego, który Auerbach rozwija jako przeciwieństwo „naiwnego" Homera i głębokiego opowiadacza biblijnego. Platon używa swych poetyckich pharmaka-mimesis (repetycji, ,mania”, dialektyki, pisma) w sposób bardziej elastyczny i przewrotnie dowcipny niż jego platońscy następcy.

\section{Porządek Arystotelesowski}

Sam będąc poetą, Platon skazał poetów na wygnanie.

Jednak gdy pojawił się filozofujący krytyk literatury, Arystoteles, przyjmował poetów $z$ otwartymi ramionami. Obwołał on Homera, podobnie jak Platon, pierwszym z poetów. Wskazałem już wcześniej przykłady sławienia w Poetyce właśnie tego u Homera, co było punktem wyjścia Platońsko-Sokratesowskiej krytyki w Państwie, a więc udramatyzowanego opowiadania ,mimetycznego". W Poetyce Arystotelesa, tak jak i u Platona, mimesis jest pojęciem kluczowym, stanowi „masterconcept" ${ }^{32}$; Arystoteles jednak nie tylko odwraca Platońskie wartościowanie mimesis, lecz w taki sposób zmienia owo pojęcie, że „w końcu oznacza ono coś zupełnie przeciwnego, niż miał na myśli Platon" 33 .

Przede wszystkim Arystoteles próbuje uczynić w miarę wygodne w użyciu pojęcie $\mathrm{z}$ tego, co - jak zauważyliśmy - u Platona było płynne, pełne sprzeczności i wieloznaczne. Poniekąd mu się to udaje, albowiem właśnie mimesis Arystotelesa stała się pojęciem powszechnie używanym w dzisiejszej historii estetyki, czasem tylko przyćmiewanym przez Platońskie obrazoburstwo. Jednak teoria powieści i narratologia poszły śladem Arystotelesa, mimo że czasem pojawiały się reminiscencje platońskie pod postacią tworzenia paradoksów albo wręcz prawdziwej anti-mimesis. Arystoteles to nie poeta skazujący poetów na wygnanie, przeciwnie: jest systematykiem filozofii goszczącym poetów w swoim systemie.

Nadaje nowe funkcje mimesis definiując je przez użycie pojęć ,,mythos" i ,praksis". W rozdziale VI Poetyki definiuje tragedię - najwyższą w jego mniemaniu formę literatury - jako ,naśladowcze przedstawienie $\left\langle\right.$ imitację ${ }^{34}$ akcji poważnej [mimesis prakseos]" $\left(1449^{\text {b }} 24\right)$. Nieco dalej w tym samym rozdziale dowiadujemy się, że to mythos dramatu dokonuje owej imitacji akcji (,,prakseos o mythos e mimesis", 1450ª). Rzecz charakterystyczna: w języku szwedzkim trudno dokonać rozróżnienia między mythos a praksis, oba terminy tłumaczy się po prostu jako ,akcja”. Także u Arystotelesa pozostają one blisko: są „imitującymi” przekładami samych siebie. Mythos to „struktura zdarzeń”, którą Arystoteles w dalszej części rozdziału VI nazywa ,duszą tragedii” $\left(1450^{a} 36,38\right)$. Praksis nie jest przypadkową akcją, to raczej jedno poważne, skończone i posiadające odpowiednią wielkość (,teleia", $1449^{\mathrm{b}} 25$ ) zdarzenie. W rozdziale VII pojawia się słynna definicja praksis jako akcji ,pełnej, skończonej i posiadającej określoną wielkość” (1450 $\left.{ }^{\mathrm{b}} 24-27\right)$. Nieco dalej w tym samym rozdziale Arystoteles podkreśla, jak bliskie sobie są mythos i praksis, porównuje oba pojęcia do pięknej istoty, traktowanej jako działająca organicznie całość $\left(1450^{\mathrm{b}} 34-1451^{\mathrm{a}} 6\right)$.

\footnotetext{
${ }^{32}$ Zob. E $1 \mathrm{~s} \mathrm{e}$, Aristotle's Poetics, s. 12.

33 Zob. E I s e, Plato and Aristotle on Poetry, s. 74.

${ }^{34}$ Tu przekład polski Podbielskiego uzupełniono wersją przyjętą przez Melberga. [Przypis tłum.]
} 
Już w tym zwartym streszczeniu równie zwartego rozumowania Arystotelesa uwidoczniło się kilka osobliwości:

1. Mimesis Arystoteles definiuje poprzez mythos i praksis, co kieruje pojęcie w stronę czasu i akcji, mimesis Platona zbliża się zaś do obrazu i odzwierciedlenia.

2. Mythos jest pojęciem porządkującym, umożliwiającym widzenie dzieła literackiego jako całościowej struktury.

3. Praksis odnosi się do akcji lub ciagów zdarzeniowych już ustrukturowanych, które ujmować można jako celowe i pełne znaczenia.

Czy w ten sposób powstała odtrutka na mimesis Platońską? Czy w poetyce przyjęto jakiś porządek pojęciowy?

Mimesis to pole, na którym szybkie odpowiedzi są kuszące, ale nieopłacalne. Zawieszam zatem pytania i zatrzymuję się przy osobliwościach. Mam na myśli sposób, w jaki Arystoteles rozszerzył i zmienił funkcję Platońskiej mimesis oraz na nowo ustanowił ład wśród pojęć porządkujących, tj. mythos i praksis.

Wielu komentatorów zwróciło uwagę, że mimesis Arystotelesowska jest bardziej twórcza i produktywna w porównaniu z Platońską, uważaną za czysto odtwórczą. Else utrzymuje, iż Arystoteles definiuje sztukę jako mimesis, artystę zaś jako twórce, mimesis zatem to tworzenie. Poeta jest mimetykiem „na mocy tego, iż jest stwórcą" 35 - pisze, a gdzie indziej dodaje: „Poeta [...] to mimetyk w tym wymiarze, w jakim jest twórcą. [...] Naśladownictwo trzyma się rzeczy. Mimesis Arystotelesa tworzy rzecz" ${ }^{36}$. Ricoeur odczytując Arystotelesa widzi mimesis jako aktywną ingerencję, która wykoleja przeżyte rzeczywistość/czas (,l'experience temporelle vive" ${ }^{37}$ ) $\mathrm{z}$ wyznaczonego toru i przenosi je do państwa fikcji, mimesis jest „emblematem owego décrochage [...] instalującego literackość dzieła literackiego" ${ }^{38}$. Podkreśla zatem, że mimesis Arystotelesowska to aktywność, twórczość, i zakłada w ten sposób zdecydowaną różnicę wobec Platońskiej mimesis jako pasywnego odzwierciedlenia. Arystotelesowską konstelację mimesis-mythos-praksis thumaczy zatem nie jako ,imitację” albo „reprezentację", ale jako „la mise en intrigue": tworzenie ,intrygi", jako mythos akcji.

Jest zatem jasne, iż mythos/praksis to płodne pojęcia nadające mimesis charakter dynamiczny przez wbudowanie w nią elementu temporalnego, to coś, czego - jak zauważyliśmy - osobliwie brak u Platona (wystarczy porównać jego paradoksalną definicję czasu jako obrazu/odzwierciedlenia wieczności w Timajosie (37 D). Mówiąc ściślej: Arystoteles „temporalizuje” mimesis poprzez ujęcie mythos/praksis jako całości sekwencji początek-środek-koniec, a zarazem wyobrażając sobie dzieło sztuki jako pewnego rodzaju „,potem”, zawsze posiadające jakieś „,przedtem”, mianowicie praksis akcji. Być może, i sama praksis ma jakieś „przedtem”, ponieważ praksis jest zorganizowanym już ciaggiem zdarzeń.

„Przed” i „po”. Dzieło sztuki imituje to, co poprzedzało je w czasie, ma jednak i następstwa w imitujących reakcjach widza. Platon niepokoił się, jak pamiętamy, z powodu etycznego oddziaływania sztuki, natomiast Arystoteles trzyma się psychologii i kilkakrotnie powraca do wywołującego dreszcze przerażenia

${ }^{35} \mathrm{E} 1 \mathrm{~s}$ e, Plato and Aristotle on Poetry, s. 106.

${ }^{36}$ E I s e, Aristotle's Poetics, s. 12.

${ }^{37} \mathrm{R}$ i c o e u r, op. cit., s. $55 \mathrm{n}$.

${ }^{38}$ Ibidem, s. 76. 
(,phobos”) i współodczuwania („,eleos”), które tragedia powodować ma u widza, powtarzającego-imitującego w ten sposób to, co przedstawia się na scenie.

Widz naśladuje. Nietrudno pojać, co też naśladuje. Także dzieło przez niego widziane-słyszane-czytane naśladuje, nie jest jednak równie oczywiste, co w takim przypadku bywa naśladowane. W rzeczy samej to standardowa kwestia w estetyce: właściwie co imituje imitacja artystyczna? Odpowiedź zmieniała się w czasie - były to np. ideał, tradycja, natura czy rzeczywistość. Wybitny XVIII-wieczny estetyk zajmujący się mimesis, Johann Joachim Winckelmann, nie miał wątpliwości co do odpowiedzi, podał jąjuż w tytule wywierającego w swoim czasie duży wpływ pamfletu: Gedanken über die Nachahmung der griechischen Werke in der Malerei und Bildhauerkunst. Dla Winckelmanna liczyło się zatem naśladowanie (,nachahmen”) dzieł antycznych. Polemizował przy tym z najbardziej w owych czasach rozpowszechnioną inną możliwością - z ,naturą", przywołując następujący przykład:

Nic nie ukazałoby lepiej przewagi naśladownictwa starożytnych nad naśladownictwem natury, niż gdyby wziąć dwójkę młodzieńców obdarzonych talentem równie pięknym i kazać jednemu studiować starożytnych, drugiemu li tylko naturę. Ten drugi tworzyłby naturę taka, jaką ją zastał: będąc Włochem malowałby, być może, figury, niczym Caravaggio, jako Holender, gdyby mu się poszczęściło, niczym Jacob Jordans, jako Francuz - niczym Stella, pierwszy zaś tworzyłby naturę zgodnie $z$ jej wymaganiami i malowałby figury, niczym Rafael ${ }^{39}$.

Sztuka naśladownictwa - podążam za Winckelmannem - powinna zwracać się ku starożytnym, czyli ku antykowi, a więc ku dziełom sztuki greckiego antyku, poniewaź ów pierwowzór wskazuje właściwy kierunek także w naturze: dopiero poprzez ogląd natury via obrazy klasyczne widzimy ją tak, jak tego chce i ,wymaga". Naśladowanie jest warunkiem koniecznym sztuki: zawsze istnieje jakaś „,sztuka” albo „natura” przed „sztuką”. Kiedy jednak rozumiemy naśladownictwo i używamy go prawidłowo, staje się ono przywilejem: stąd wiedzie jedyna słuszna droga ku „naturze”. Naśladowanie nie jest losem ani trywialnym, ani żałosnym, raczej daje artyście szanse potwierdzenia siebie/swego ,ja".

Także mimesis Platońska jest twórczością, ponieważ potrafi, jak pamiętamy z Timajosa, stworzyć świat. Przynosi jednak również zagrożenia, czymże jest bowiem Arystotelesowska groza w porównaniu ze ślepota, która ogarnia platońską duszę w chwili najjaśniejszego widzenia? Mimesis Platona jest twórcza, tyle że na koszt twórcy.

Arystoteles raczej nie wyobrażał sobie, iż ,dzieło sztuki” mogłoby być, jak twierdzi Winckelmann, imitowane w mythos dzieła sztuki. Jaką jednak widział akcję (,praksis") przed akcją w dziele sztuki, w jego mythos? Komentatorzy zgodni są co do tego, iż zarówno mythos, jak i praksis to pojęcia porządkujące; Ricoeur uważa nawet, że u podstaw mythos leży „sama zasada porządku” ${ }^{40}$. Arystoteles zaś podkreślał, iż praksis to celowa całość zorganizowana zgodnie z sekwencją początekśrodek-koniec. Innymi słowy: nie mamy do czynienia z dowolnymi zdarzeniami, ale $\mathrm{z}$ łańcuchem zdarzeń w swej celowości dającym wrażenie konieczności, nie obar-

${ }^{39}$ J. J. W in c k e l m a n n, Gedanken über die Nachahmung der griechischen Werke in der Malerei und Bildhauerkunst. W: Winckelmanns Werke in einem Band. Berlin-Weimar 1982, s. 1213. Wyd. 1: 1755.

${ }^{40} \mathrm{P}$. R i c o e ur, Time and Narrative II. Transl. K. McL a u g h l i n, D. P e ll a u e r. Chicago 1985, s. 7. 
czonym czynnikami przypadkowymi, elementami dowolnie wybranymi czy też lukami czasowymi. Praksis Arystotelesa ma, jak się zdaje, strukturę narracyjna, jeszcze zanim narracja instalować zaczyna swój mythos. We wszystkich przypadkach jednak praksis trudno odróżnić od mythos. Zarazem rozróżnienie praksis od mythos jest warunkiem koniecznym każdej narracji: oba pojęcia mają się do siebie tak jak „przed” do „po”, będących Arystotelesowskim warunkiem twórczości.

Trudności w różnicowaniu tych pojęć oraz ich plenność świetnie ilustruje współczesna narratologia, mocno zainspirowana przez Arystotelesowskie, protostrukturalistyczne spojrzenie na akcję opowieści jako celową całość. Parę praksis-mythos zmodernizowano np. na story-plot, fabula-siużet, historie-récit, podczas gdy stary termin ,mimesis" zastapiono obszerną i skomplikowaną nomenklaturą służącą do opisu wszystkich wariantów relacji „przed-po" zawartej w owych parach pojęciowych. Niektórzy badacze doszukali się w opowiadanych tekstach jeszcze jednego poziomu, dyskursu opowiadania, nie mającego odpowiednika u Arystotelesa, ale za to poprzednik u Platona/Sokratesa w wykładzie z Państwa na temat różnicy między „co” a ,jak” opowiadania.

Narratologia nie jest w stanie pochwalić się ujednoliceniem pojęć, co - jak sądzę - wskazuje na słabość podstawowej dystynkcji wywodzącej się z Arystotelesowskiej pary pojęć praksis-mythos. Sprawia to wrażenie, iż analitycy opowiadania nigdy nie potrafili zdecydować się, czy mythos opowieści odnosi się do (albo „reprezentuje”, albo „przedstawia”, albo „naśladuje”, albo „odzwierciedla”) i emanuje z nienarracyjnej albo nieznarratywizowanej „rzeczywistości”, czy może jest projekcją mythos opowiadania. Pierwsza alternatywa thumaczy lepiej od drugiej zbijającą $z$ tropu różnorodność terminologiczną panującą w narratologii oraz tendencję do zaczynania wszystkiego od początku w obliczu każdej nowatorskiej opowieści. Gdyby jednak praksis okazała się produktem mythos, skomplikowałoby to nieuchronnie porządek ,,przed-po” będący temporalną treścią owej dystynkcji. Porządek ten prowadzi z kolei do pierwszej alternatywy, mianowicie, iż praksis to owo „o”, o którym opowiadanie opowiada, lub też nieznarratywizowana „rzeczywistość" poprzedzająca w założeniu drugi ,akt tworzenia" w opowieści.

Naszkicowaną tu trudność w rozróżnieniu praksis od mythos rozwija z wielkim rozmachem Ricoeur. Używa on Arystotelesowskiej, a nie Platońskiej mimesis - i to zarówno w odniesieniu do świata zjawisk, jak i do świata znaków - jako swego rodzaju pojęcia ekumenicznego na określenie fenomenologii czasu, narratologii i hermeneutyki. Ricoeur twierdzi, iż mythos opowieści odznacza się zarówno pewnym ,przed”, jak i ,po”. To, co znajduje się ,przed”, sugeruje terminami „doświadczenie przeżyte” (różne od opowieści i fikcji) ${ }^{41}$, ,przednarracyjne doświadczenie" 42 albo przez powtarzające się terminy, np. „żywe doświadczenie czasu [,l'expérience temporelle vive]”. Natomiast to, co istnieje „potem”, odnajdujemy w domenie ,aplikacji” hermeneutycznych, a przekazane zostaje, jeśli chodzi o opowieść, przez akt czytania: „to przez akt czytania literatura powraca do życia, czyli do praktycznego i afektywnego obszaru bytu" ${ }^{43}$. Oznacza to, że czyta-

41 Ibidem, s. 5.

$42 \mathrm{R}$ i c o e u r, Temps et récit $\mathrm{I}$, s. 113.

${ }^{43}$ P. R i c o e ur, Time and Narrative III. Transl. K. McL a u g h l i n, D. P ell a u e r. Chicago 1988 , s. 101 . 
nie nie jest celem samym w sobie i nie prowadzi, z idealistycznego punktu widzenia, do opowieści, ale raczej kieruje od niej do czegoś, co znajduje się po niej, a co Ricoeur określa terminami takimi, jak ,refiguracja” i „reorientacja”: „Dopiero to, co przychodzi po akcie czytania, decyduje, czy zastój dezorientacji [stanu, w którym znajdują się zarówno tekst, jak i akt czytania - A. M.] będzie zaczątkiem dynamiki reorientacji" ${ }^{44}$.

„Przeżycie”, ,doświadczenie”, ,,życie”, wszystko, co dla Ricoeura leży ,przed” opowieścią, „po" niej albo „poza” nią, nie jest jednak, jak się zdaje, przypadkowym chaosem zjawisk i postrzeżen. W zacytowanych tu słowach Ricoeur sugeruje, iż obszary praksis leżące ,przed”, „po” itd. mają status niemal przed- albo pozajęzykowy, są czystymi przeżyciami, jednocześnie jednak twierdzi, iż są już zorganizowane symbolicznie: ,Jeśli w ogóle da się opowiedzieć akcję, to dlatego, iż jest ona zawarta już w znakach, regułach, normach, jest zawsze od początku przekazywana za pośrednictwem s y mboli" "45. Najwyraźniej i dla Ricoeura opowieści nie mają jakiegoś zewnętrza albo czegokolwiek poza tekstem symboli ${ }^{46}$, zarazem jednak podjęta przez niego próba przeprowadzenia mimesis od poetyki ku hermeneutyce zakłada istnienie presymbolicznego ,przed” i postsymbolicznego ,po" tekstu.

Chciałem w ten sposób pokazać, iż Ricoeur potęguje aż do bezpośredniego przeciwieństwa trudności związane z Arystotelesowską dystynkcją praksis-mythos. Życzliwe uznanie dla Arystotelesowskiej mimesis sztuki wydaje się nasycone jeszcze intensywniejszą tęsknotą do ucieczki o d sztuki (a także od opowieści, tekstu, języka) - do zagadkowego stanu, który sławi się jako praksis. Także i ten konflikt w tekście Ricoeura potęguje napięcie pojawiające się już u Arystotelesa i stanowiące, być może, nieuchronne następstwo jego prób wprowadzenia porządku temporalnego w mimesis poetyki.

\section{Podobieństwo i różnica}

Spojrzenie estetyczne, na którym próbowałem skupić się w przypadku Arystotelesa (a w odniesieniu do naszych czasów - Ricoeura) zmierza, jak sądzę, w stronę przeciwną niż sztuka: ku jakiemuś „,przed” albo „po”. Zapytać, oczywiście, można, czy takie dążenie $w$ istocie trzeba łączyć z poetyką, tj. nauką o języku sztuki i sztuce języka? Ponadto: jak ma się ono do mimesis Platońskiej, do manifestowanego przez Platona dystansu wobec rzeczywistości artystycznej i do równie charakterystycznej Platońskiej wizji wiedzy i słowa jako oślepiającego obrazu? Czym jest owo ,ja”, które, jak uważam, „potwierdza się” u Arystotelesa, a któremu ,przeczy” Platon?

Jest rzeczą kusząca, by dalej ekstrapolować owe odmienne podejścia do ujęć skrajnie różnych, chciałbym jednak zakończyć ten przegląd mimesis na poziomie, na którym Platon i Arystoteles, na przekór przeciwieństwom, pracują jak się zdaje, nad tym samym, wspólnym problemem, odnoszącym się nie tylko do sztuki

${ }^{44}$ Ibidem, s. 170.

${ }^{45} \mathrm{R}$ i c o e u r, Temps et récit I, s. 91.

46 Odnoszę się, rzecz jasna, do słynnego zdania: „Il n'y a pas de horse-texte”, i wywodu ukrytego przeciwnika hermeneutyki Ricoeura, J. De r rid y (De la grammatologie. Paris 1967, s. 227) o piśmie oraz o przyczynie. 
i obrazu, lecz przede wszystkim do języka. Wspólne jest bowiem przekonanie obu filozofów, iż język, by tak rzec, wskazuje poza siebie i że język sztuki wyraźniej niż inne języki problematyzuje to „poza-siebie”. Każdy z nich odnosi się do owej niepewności, którą wywołuje w nas język sztuki, a którą współczesna lingwistyka nazwała funkcją poetycką albo literackością. W niezrównany sposób wyraził to Paul De Man: „dlatego też nie jest pewne a priori, że literatura może być miarodajnym źródłem informacji o czymkolwiek innym niż o jej własnym języku" ${ }^{47}$. Platon i Arystoteles udzielili różnych odpowiedzi na to samo, domagające się od nas odpowiedzi, ale ostatecznie nierozstrzygalne pytanie, mianowicie o kwestię relacji między literaturą, zatem i językiem, a rzeczywistością.

Kwestia ta wymaga odpowiedzi z następującego powodu: znak językowy zawsze odnosi się do rzeczywistości „poza” własną rzeczywistością znaków, problemu nie da się „rozwiązać”, ponieważ referencyjna funkcja języka podporządkowana lub przyporządkowana jest innym funkcjom językowym. (To samo odnosi się do każdego języka, podejrzewam jednak, iż język literacki zaznacza własności tropologiczne i funkcje retoryczne bardziej wyraziście niż inne języki.) Już opisanie tego zagadnienia za pomocą pojęć wydaje się niemożliwe, ponieważ wplątywałoby w metaforykę wizualna, w którą sam już wpadłem, tj. w wyobrażenia o jakimś „ponad”, ,poza” albo „wewnątrz” języka.

Arystoteles próbuje znaleźć rozwiązanie odkładając poszczególne komponenty na osi czasowej: literatura traktuje o czymś, mianowicie o praksis, która jest od niej wcześniejsza. Platon z kolei wybiera paradoks: język wchodzi, według niego, w relację odzwierciedlającą wobec rzeczywistości, podczas gdy właściwa rzeczywistość (,ousia") ma już charakter obrazu czy też fantazji wizualnej. Zarówno Platon, jak i Arystoteles poszukują ,,przed”, ,poza” albo „na zewnątrz" - poszukują tego samego, co pragnie znaleźć każdy czytelnik literatury: do czego odnosi się i o czym traktuje język literatury. O ile Platon wciąż popada w fantazje mitologiczne i metaforykę wizualną kiedy znaleźć ma słowo na opisanie owego prawdziwego "poza" i ,przed", o tyle Arystoteles zadowala się podkreśleniem aspektu temporalnego i jakże tajemniczym słowem ,praksis”. Obaj zgodni są jednak, że pojęcie „mimesis" we właściwy sposób oddaje związek literatury z rzeczywistością, choć znaczenie tego pojęcia zmienia się od Platońskiego „samonegującego" odzwierciedlenia - do Arystotelesowskiego „samopotwierdzającego" przedstawienia. We wszystkich wariantach, interpretacjach i przekładach mimesis zachowane zostało przy tym wyobrażenie o języku literackim jako o mniej lub bardziej podobnym obrazie/odzwierciedleniu/przedstawieniu tego, o czym w istocie traktuje i do czego odnosi się język. Nie popełnimy błędu mówiąc tu o estetyce podobieństwa lub odzwierciedlenia.

Mimesis zawiera też inny wymiar: istnieje tu także różnica.

Różnica, dyferencja, pęknięcie i skierowany ku powrotowi antyruch odnowienia pojawia się już u zaprezentowanych przeze mnie fundatorów estetyki podobieństwa, przeczuwam go w paradoksach Platona i w jego ,grach" językowych oraz w ironicznej i repetytywnej praksis dialogów filozoficznych, myślę też o owej temporalności, odkrytej przez Arystotelesa w aktywności mimetycznej. Wskazałem również na wzorzec repetytywny w Iliadzie, działający jednak nie przez powtórzenie i odzwierciedlenie, ale przez odzyskiwanie i odnowę.

${ }^{47}$ P. De M a n, The Resistance of Theory. Minnesota 1986, s. 11. 
Wymienione czynniki tworzą napięcia mimetyczne, które ujmuję w pary terminów możliwie prostych, nazywam je p od obieńs twe m-różn i c a ich ślady odnajduję następnie w przykładach jako napięcia między p o w tór z e n i e m- odnową a bliskością-dystansem. Nie uzyskamy w ten sposób nowych odpowiedzi na pytanie, do cze g o odnosi się język albo o czy m traktuje literatura, powstają raczej tylko nowe pytania; celem owego wstępnego przeglądu było wskazanie, iż pytania te zawierają się już w odpowiedzi Platona.

Ze szwedzkiego przełożył Jan Balbierz 